Article

\title{
Impact of Information and Communication Technology Infrastructure on Economic Growth: An Empirical Assessment for the EU Countries
}

\author{
Elena Toader ${ }^{1}$, Bogdan Narcis Firtescu ${ }^{2, *(\mathbb{D})}$, Angela Roman ${ }^{2}\left(\mathbb{D}\right.$ and Sorin Gabriel Anton ${ }^{2}$ (D) \\ 1 Faculty of Medicine, Grigore T. Popa University of Medicine and Pharmacy of Iasi, 700511 Iasi, Romania; \\ toader.elena@yahoo.com \\ 2 Faculty of Economics and Business Administration, Alexandru Ioan Cuza University of Iasi, 700505 Iasi, \\ Romania; aboariu@uaic.ro (A.R.); sorin.anton@uaic.ro (S.G.A.) \\ * Correspondence: firtescu@uaic.ro; Tel.: +40-751-226-692
}

Received: 25 September 2018; Accepted: 15 October 2018; Published: 17 October 2018

\begin{abstract}
The accelerated development of information and communication technology (ICT) over the past two decades has encouraged an increasing number of researchers to examine and measure the impact of this technology on economic growth. Our study aims to identify and evaluate the effect of using ICT infrastructure on economic growth in European Union (EU) countries for a period of 18 years (2000-2017). Using panel-data estimation techniques, we investigate empirically how various indicators of ICT infrastructure affect economic growth, proxied in our study by GDP per capita. Within the estimates, we have included some macroeconomic control variables. Our results indicate a positive and strongly effect of using ICT infrastructure on economic growth in the EU member states, but the magnitude of the effect differs depending on the type of technology examined. Regarding the impact of macroeconomic factors, our estimates indicate that inflation rate, unemployment rate, the degree of trade openness, government expenditures, and foreign direct investments would significantly affect GDP per capita at EU level. The findings are broadly similar to the theoretical predictions, but also to the findings of some relevant empirical studies. Our research reveals that ICT infrastructure, along with other macroeconomic factors, is an important driver of economic growth in EU countries.
\end{abstract}

Keywords: ICT infrastructure; economic growth; macroeconomic variables; EU countries; panel data

\section{Introduction}

Significant development of information and communication technology (ICT) over the past two decades has encouraged many researchers to investigate its economic implications, notably the contribution of ICT to increasing productivity, promoting economic growth, and reducing poverty. Most studies in the field have indicated that information and communications technology is a key factor in the economic and social development of the countries because it has positive effects on economic growth, productivity, and employment. Also, international organizations such as the United Nations, the International Telecommunications Union, the OECD, and the World Bank argue that the ICT sector is a key driver of sustainable development. A study realized by the World Economic Forum [1] indicates that an increase in the digitization of a country by 10 percent would lead to a 0.75 percent increase in GDP per capita, and a 1.02 percent drop in the unemployment rate. According to the OECD [2], information communication technology plays a major role in reducing poverty by creating new sources of income and new jobs, but also by reducing the cost of poor people's access to health and education services. 
ICT includes "hardware, software, networks, and media collection, storage, processing, transmission, and presentation of information (voice, data, text, images)" [3] (p. 3). In accordance with Pradhan et al. [4], information and communication technology infrastructure refers to "digital telephone network, mobile phones, Internet capability, Internet servers and fixed broadband, and other technologies".

Rapid expansion of ICT is of crucial importance for economic growth for many reasons: the use of this technology enables the various participants in economic and social life to have quick and easy access to information and knowledge [5]; ICT enables companies to communicate faster and better so they reduce production costs and improve productivity [6]; ICT also allows access to new markets, lower capital costs as a result of increasing the efficiency of the functioning of financial markets, reduces regional discrepancies in incomes and productivity, allows access to human capital through tele-networking [4]; the use of ICT, in particular, Internet access, can promote the sustainable development of entrepreneurship and small and micro businesses because it reduces the difficulty of financing them by mitigating information asymmetry and reducing agency cost [7].

According to some authors [8-15], ICT can influence economic growth through several significant channels, namely: the production of goods and services within the ICT sector directly contributes to the creation of value-added goods and services in the economy; the use of ICT goods and services as inputs in the production of other goods and services; increasing productivity in the ICT sector contributes to increasing the overall productivity of the economy; the use of ICT in other sectors of the economy contributes to improving its efficiency and productivity.

The objective of this paper is to examine the effect of using ICT infrastructure on economic growth in EU28 countries, for a period of 18 years (2000-2017). Using the Generalized Method of Moments, we investigate empirically how different indicators measuring ICT infrastructure affect economic growth, proxied in our study by GDP per capita. As part of our estimates, we have also included some macroeconomic control variables with the purpose of highlighting their influence on GDP per capita.

The study contributes to the specialized literature in at least two ways. First, we examine the effect of ICT infrastructure on economic growth using four different measures of ICT infrastructure, while other previous empirical studies have used only one or two indicators of ICT infrastructure. Secondly, our research focuses on the $28 \mathrm{EU}$ member countries, while after our knowledge, there are only a few studies, especially recent, which are focused on the EU countries, and which have analyzed the impact of ICT infrastructure on economic growth.

The remainder of this paper is organized as follows. Section 2 reviews previous empirical studies that have analyzed the effects of ICT on countries' economic and social development, especially on economic growth. Section 3 presents the data and the analyzed variables, and describes the empirical methodology. Section 4 highlights and discusses the results of our empirical study, and the last section contains concluding remarks.

\section{Review of Empirical Studies}

The impact of information and communication technology (ICT) on the economic and social development of the countries has been investigated over the past three decades by many authors who have used different methodologies, data sources, and different time periods either at the country level, or at the level of a panel of countries. Most empirical studies have concluded that increasing ICT use can lead to GDP growth, productivity, and employment.

The literature review reveals that some empirical studies have focused on investigating the impact of ICT on economic growth, concluding that the ICT sector is a major contributor to economic growth. Other studies have assessed the impact of the ICT sector on economic growth by controlling other determinants of growth, and have indicated that the development of the ICT sector is one of the key drivers of the economic growth. Another category of studies aimed to analyze the extent to which there is a causal relationship between ICTs and economic growth. Regarding the latter, most researchers have concluded that ICT is both a cause and a consequence of economic growth. 
Some studies have discussed the importance of using ICT in some important sectors of the economy, such as the banking sector, highlighting the contribution of this technology to facilitating the relationship between banks and their customers, and improving banking performance [16-18].

In 1998, using data for 27 countries in Central and Eastern Europe for the period 1990-1995, Madden and Savage [19] analyze the empirical relationship between investment and economic growth. The results of the study highlight, in particular, a positive relationship between investment in telecommunication infrastructure and economic growth. Roller and Waverman [8] examine the impact of telecommunication infrastructure on economic growth in 21 OECD countries, between 1970 and 1990. The authors find that telecommunications infrastructure positively and significantly affects economic growth. The results indicate a $2.8 \%$ GDP growth, with a $10 \%$ increase in telecommunication infrastructure. In another study focusing on OECD countries, Datta and Agarwal [20], using the dynamic panel data method for 22 countries, investigate the long-term relationship between telecommunications' infrastructure and economic growth. Research reveals a significant and positive correlation between telecommunications' infrastructure and economic growth. Similarly, but with reference to 105 countries, which are divided into different groups (region and per capita income), Shiu and Lam [21] study the causal relationship between telecommunication development and economic growth. The authors find that there is a bidirectional relationship between telecommunication development and economic growth for European countries, and those in the high income countries. For countries in other regions and the lower income group, the relationship is generally unidirectional (from real GDP to telecommunications development). Therefore, for less developed countries, the authors point out that telecommunication development is not an important determinant of economic growth. Cieślik and Kaniewsk [22] analyzes the relation between telecommunication infrastructure and the regional level of income using panel data for 49 regions in Poland during 1989-1998. The authors find a positive and statistically significant causal relationship between telecommunication infrastructure and income at the regional level, but the causality is from telecommunications to income.

The positive impact of ICT on economic growth is also evidenced by Czernich et al. [23], which analyzes the effects of broadband infrastructure on economic growth for a group of 25 OECD countries in 1996-2007. The authors find that a $10 \%$ increase in the broadband penetration rate would cause an annual GDP per capita growth of $0.9-1.5 \%$.

One strand of literature focuses on examining the effects of Internet use in the economy, particularly on economic growth. Thus, using data for 207 countries, from 1991-2000, Choi and Yi [24] show the positive and significant role of the Internet for economic growth. In the estimates, the authors include some control variables (such as investment ratio, government consumption ratio, and inflation), and the results are largely in line with literature; respectively, investments have a positive impact on economic growth over time, and government consumption and inflation have a negative effect. Another study of interest [6] aims to identify whether Internet use has a direct impact on economic growth or whether the use of the Internet influences economic growth more indirectly through trade. Using data covering the period 1990-2008 and targeting 162 countries, the author finds that Internet use has no direct impact on economic growth, but indirectly through trade. Empirical results indicate that a 10 percentage point increase in Internet usage would increase the growth of the openness rate by 3.9 percentage points, which in turn would boost economic growth by 0.17 percentage points. Salahuddin and Gow [25] examines the effects of Internet usage, financial development, and trade openness on economic growth. The empirical results indicate a long-term positive and significant relationship between Internet usage and economic growth, but also between financial development and economic growth. The effects of using the Internet are also analyzed with reference to companies. Thus, Chen et al. [7] investigates how Internet use affects the access of entrepreneurs or small and micro-businesses to external financing. Empirical results indicate that Internet use plays a positive role in accessing companies' external finance by mitigating financing difficulties, thus contributing to their sustainable development. The authors also point out that using the Internet would allow 
more profitable projects to have access to external funding, so that access to the Internet can improve social welfare altogether. Another empirical research [26] focuses on investigating the influence of the Internet on labor productivity for 108 countries in the period 1995-2010. The results indicate a positive and significant effect of the Internet on labor productivity, and the authors support the need for governments to take different measures to increase the demand for the Internet and to expand its use.

Another strand of literature analyzes the effects of ICT investments on countries' economies. Using the Generalized Method of Moments, Nasab and Aghaei [27] investigates the impact of investments in ICT on economic growth in seven OPEC member countries for the period 1990-2007. The authors find that ICT has a significant positive impact on economic growth in the sampled countries, and underlines the need to adopt specific policies to encourage ICT investments to boost economic growth. Qiang et al. [28] assesses broadband's impact on economic growth over the period from 1980 to 2006. Empire results indicate that a 10 percentage point increase in fixed broadband penetration would lead to a GDP growth per capita of $1.21 \%$ for developed economies, and $1.38 \%$ in the case of emerging economies. Crandall and Singer [29] examine the economic impact of broadband investments on consumer welfare, job creation and economic output in the US over the period 2003-2009. Authors find that increasing broadband investments would lead to increased employment and GDP. Dimelis and Papaioannou [30] analyzed the possible effects of foreign direct investment (FDI) and ICTs on productivity growth, in the case of a sample of 42 developing and developed countries for the period 1993-2001. The results of the analysis indicate a positive and significant impact of ICT in all groups of countries, but the effect would be greater for developing countries. With regard to FDI, econometric estimates show a positive and significant impact on developed countries, as well as a positive but insignificant impact on developing countries. Using panel data for the period 2005-2009, Thompson and Garbacz [31] aim to identify the impact of mobile and fixed broadband adoption on economic growth. The authors find that mobile broadband has a positive and significant impact on GDP per household, but the impact size is higher for poorer countries. Zagorchev et al. [32] examines the impact of financial development and ICT on economic growth in eight countries in Central and Eastern Europe for the period 1997-2004. Research results indicate that financial development and increased investment in telecommunications technology contribute significantly to GDP growth per capita. Given the positive impact of ICT on economic growth, the authors emphasize that governments' policies should provide incentives for technological development, and encourage investments in ICT. Using data for 62 countries with different levels of development, Yousefi [33] investigates whether ICT contributes to improving economic growth. The results of the study show that ICT has a bigger impact on GDP growth in upper-middle income countries than in low-income countries. The author points out that for developing countries, growth in GDP is not conditional on investment in ICT. Veeramacheneni et al. [34] analyze empirically, a sample of 10 Latin American countries during 1975-2003, for is a causal relationship between ICT and economic growth. The authors find that there is a two-way causality between ICT and economic growth in two thirds of the examined countries, and that ICT contributes to economic growth in eight of the 10 countries included in the sample.

Some empirical studies $[14,15,35,36]$ found that increasing ICT use is a strong driver of economic growth, and stressed the need for countries to focus on promoting the use of ICT, in particular in order to increase its effects on economic growth. Farhadi et al. [35] focus on a panel of 159 countries over the period 2000-2009, and note that the impact of ICT use is stronger in higher income countries, while the impact is weak in countries with low levels of income. Lovrić [37] assesses the impact of ICT on labor productivity growth in 25 European developed and developing countries over the period 2001-2010. The author finds that ICT is an important determinant of labor productivity growth, both in developed countries as well as in developing countries. In addition, the author points out that a high level of education amplifies the impact of ICT on the labor productivity growth of EU developing countries.

Another study [38] investigates whether the relationship between financial development and economic growth depends on the level of development of the ICT sector. The results indicate that 
ICT diffusion has a positive and significant impact on economic growth, and the impetus of financial development can be strengthened by enhancing ICT infrastructure.

Based on economical estimates and using data for 27 European Union (EU) countries, from 2005-2011, Gruber et al. [39] note that broadband adoption has a significant positive effect on GDP, and at the EU level, the cumulative gains from broadband deployment are $32 \%$ above the cost. Pradhan et al. [40] analyze the causal relationship between the development of telecommunications infrastructure, economic growth, and four key macro-indicators, and international trade openness. Research results indicate a bi-directional causal relationship between the development of telecommunications infrastructure and long-term economic growth, both for developed countries and for developing countries. Based on the findings of the study, the authors emphasize the need for policymakers to pay attention to the development of the telecoms sector, alongside other macroeconomic variables, as long as they aim to promote long-run economic growth. In another study, Pradhan et al. [41] examine the causal link between the development of telecommunications infrastructure, financial development, and economic growth. The empirical results indicate that both financial development and the development of telecommunications infrastructure play a significant role in the economic growth of the analyzed Asian countries. Authors also find a causality between variables, both in the short and long run.

The significant role of the ICT sector in supporting economic growth is also indicated in some recent studies. Niebel [42] assesses the impact of ICT on economic growth in 59 developing, emerging, and developed countries over the period 1995-2000. The results indicate a positive impact of ICT on economic growth for the whole sample of countries. In addition, estimates for the three groups of countries show small differences between countries. Thus, the author points out that developing and emerging countries do not gain more from investing in ICT, compared to developed economies. Majeed and Ayub [43] analyze how different ICT indicators influence economic growth in 149 countries for the period 1980-2015. The empirical results indicate that the use of ICT infrastructure has a positive and significant impact on economic growth. Using panel data for 40 Sub-Saharan Africa countries covering the period 2006-2015, Haftu [44] examines the impact of telecommunication infrastructure on the region's economic growth. The author finds that expanding ICT in the form of mobile phone subscriber's growth has been an important contributor to increasing the per capita income of the region for the period under review. This is the reason for why the results indicate that a $10 \%$ increase in mobile phone penetration leads to a 1.2\% change in GDP per capita. Latif et al. [45] estimate the impact of ICT, foreign direct investment, trade, and globalization on economic growth in BRICS countries, using panel data for 2000-2014. Empirical results show that ICT has had a significant positive impact on economic growth, but that the impact may vary between countries, depending on the degree of use of ICT by those countries. Regarding the other three variables, authors also find a positive effect on economic growth. Based on G20 countries data, in another study, Pradhan et al. [4] investigates the relationship between economic growth, ICT infrastructure, consumer price index, labor force participation, and gross domestic fixed capital formation. The authors find that all four variables contribute to increasing economic growth in the analyzed countries.

Since 2007, in the context of the emergence of new innovations in the field of information technology, especially that of cloud computing technology, there is an increase in the interest of many researchers and policymakers at EU level for both the theoretical and empirical analysis of the economic effects of adoption and rapid dissemination of this new technology. According to Etro [46], cloud computing is "a new general purpose Internet-based technology through which information is stored in servers and provided as a service and on-demand to clients". The European Commission [47] emphasizes that the adoption of cloud computing technology by businesses and other organizations can lead to significant increases in efficiency across the economy. Given the positive effects of the new technology, the European Commission argues the need for European countries to support, through various measures, the rapid diffusion of cloud computing so that Europe becomes a global power in the field of cloud computing. Using data from Eurostat, Etro [46], analyzes the macroeconomic 
impact of adopting cloud computing technology in EU countries. Empirical results indicate that the rapid deployment and diffusion of cloud computing in the European economy would have a positive effect on GDP, employment, and the creation of new businesses. The author also emphasizes that policymakers should promote as quickly as possible the adoption of cloud computing, especially in the dynamic sectors of the economy.

The importance of the ICT sector, including the use of cloud computing technology for the EU economy, is underlined by the European Commission [48] in the Working Document entitled "A Digital Single Market Strategy for Europe", which is a key pillar of Europe 2020 Strategy. A more recent study [49] discusses the positive effects of the adoption and use of cloud computing by SMEs in EU countries, as well as the factors that impede the use of this technology by firms. In addition, the author emphasizes the strategies adopted at EU level to increase the use of cloud computing. Although the benefits of introducing cloud computing technology are widely discussed by both researchers and decision-makers at different levels, the statistical data offered by Eurostat [50] show that only $21 \%$ of EU businesses have used loud computing services. In addition, the data shows significant disparities between countries, namely: in some countries (Finland, Sweden and Denmark), over 40\% of enterprises used cloud computing, while in other countries (Greece, Latvia, Poland, Romania and Bulgaria), the percentage is below $10 \%$. Such a situation shows the need for policymakers at both European and national level to further support the faster adoption of cloud computing in all sectors of the economy.

Our study is added to the existing literature by providing empirical evidence regarding the impact of various ICT infrastructure indicators on economic growth in EU countries.

\section{Data and Methodology}

\subsection{Data and Variables}

Our paper investigates the effects of some ICT infrastructure indicators on economic growth in EU countries, for a period of 18 years (2000-2017). Our analysis includes 12 indicators, and the data were obtained from four available sources: the database of the International Telecommunications Union (ITU) [51], the OECD database [52], the World Development Indicators (WDI) database (World Bank) [53], and the European Commission (Eurostat) [54].

In our econometric models, the dependent variable is economic growth (EG), proxied by GDP per capita (in US dollars at current prices and Purchasing Power Parities (PPPs)). As explanatory variables, we took into account two types, namely: firstly, main explanatory variables, which are represented by four different measures of ICT infrastructure (fixed-broadband subscriptions per 100 inhabitants, the percentage of households with a broadband Internet connection via home computer, percentage of individuals using the Internet, and mobile cellular subscriptions per 100 people); the second type of explanatory variables refers to the macroeconomic control variables (gross fixed capital formation, inflation rate, unemployment rate, trade openness, inflows of foreign direct investment, general government final consumption expenditure, and the level of financial development, proxied in our study by the domestic credit to the private sector).

The description of the variables included in the analysis and the data sources are presented in Table 1.

Table 1. Definitions of the variables and the sources of data.

\begin{tabular}{ccc}
\hline Variable & Description & Data Source \\
\hline & Dependent variable & \\
\hline $\operatorname{lngdp}$ & $\begin{array}{c}\text { Gross domestic product per capita at market prices, measured in US } \\
\text { dollars at current prices and PPPs (logarithmic values) }\end{array}$ & OECD \\
\hline
\end{tabular}


Table 1. Cont.

\begin{tabular}{|c|c|c|}
\hline \multicolumn{3}{|c|}{ Independent variables } \\
\hline $\operatorname{lnfbs} 100$ & $\begin{array}{c}\text { Fixed-broadband subscriptions per } 100 \text { inhabitants } \\
\text { (logarithmic values) }\end{array}$ & ITU \\
\hline lnhbccp & $\begin{array}{c}\text { The percentage of households with a broadband Internet connection } \\
\text { via home computer (logarithmic values) }\end{array}$ & ITU \\
\hline lniuip & Percentage of individuals using the Internet (logarithmic values) & ITU \\
\hline $\operatorname{lnm} c s 100$ & Mobile cellular subscriptions (per 100 people) (logarithmic values) & ITU \\
\hline lngdfcfpgdp & $\begin{array}{c}\text { Gross domestic fixed capital formation, which includes land } \\
\text { improvements, plant, machinery, equipment purchases, the } \\
\text { construction of roads, railways, commercial and industrial buildings } \\
\text { (\% of GDP) (logarithmic values) }\end{array}$ & World Bank \\
\hline $\operatorname{lninf}$ & Inflation rate (annual average rate of change) (logarithmic values) & Eurostat \\
\hline lnunimpl & Unemployment rate, annual average (\% of active population) & Eurostat \\
\hline lnto & $\begin{array}{l}\text { Trade openness, which is the sum of exports and imports of goods and } \\
\text { services (\% of GDP) (logarithmic values) }\end{array}$ & World Bank \\
\hline lnfdipgdp & Foreign direct investment, net inflows (\% of GDP) & World Bank \\
\hline lnggfcepgdp & $\begin{array}{l}\text { General government final consumption expenditure, which includes } \\
\text { all government current expenditures for purchases of goods and } \\
\text { services (\% of GDP) (logarithmic values) }\end{array}$ & World Bank \\
\hline $\operatorname{lnfd}$ & $\begin{array}{l}\text { Financial development, proxied in our study by the domestic credit to } \\
\text { private sector (\% of GDP) (logarithmic values). Domestic credit to the } \\
\text { private sector, including the financial resources provided to the private } \\
\text { sector by financial corporations (\% of GDP) }\end{array}$ & World Bank \\
\hline
\end{tabular}

ICT has become very important in modern economy, and its effects on economic growth derive from two channels: the output of ICT-producing industries, and the output of the ICT-using industries. The first output was incorporated as inputs in the ICT-producing industries. To identify the effects of ICT on productivity and economic growth, a production function as one in the equation below can be considered:

$$
Y_{t}=Y\left(Y_{t}^{I C T}, Y_{t}^{O}\right)=A_{t} F\left(C_{t}, K_{t}, H_{t}, L_{t}\right)
$$

where: $Y$ (aggregate value added, at time $t$ ) is assumed to consist of ICT goods and services $Y_{t}^{I C T}$, as well as of other production $Y_{t}^{O}$. The aggregate inputs are produced from ICT capital $C$, other (i.e., non-ICT) physical capital $K$, human capital $H$, and labor $L$. The level of technology is here represented in the Hicks neutral or output augmenting form by parameter $A$. The estimation of the impact of ICT investment has been approached in three principal ways in the literature: production function estimation, growth accounting, and applied growth theory [55]. Related to the first approach, supposing that the function assumes the simple Cobb-Douglas form, with the time index being suppressed:

$$
Y=A C^{\alpha_{c}} K^{\alpha_{k}} H^{\alpha_{h}} L^{\alpha_{l}}
$$

Taking the natural logarithm on both sides, the following equation results:

$$
\ln Y=\ln A+\alpha_{c} \ln C+\alpha_{k} \ln K+\alpha_{h} \ln H+\alpha_{n} \ln N
$$

Applying the difference on terms from Equation (3) with respect to time, gives the illustration of the representation on growth (see Equation (4)), the variables indicating the rate of change:

$$
\dot{Y}=\dot{A}+\alpha_{c} \dot{C}+\alpha_{k} \dot{K}+\alpha_{h} \dot{H}+\alpha_{n} \dot{N}
$$


Taken into consideration equations number three and number four, the linear panel data models using fixed, random, first differenced, or dynamic options can be estimated, as explained below.

\subsection{The Linear Panel Data Models—An Overview}

The basic linear panel model can be defined using some suitable restrictions of the following general model presented in Equation (5):

$$
y_{i t}=\alpha_{i t}+\beta_{i t} x_{i t}+\mu_{i t}
$$

where $i=1,2 \ldots n$ is the individual group (country) index, $t=1,2 \ldots T$ is the time index and $\mu_{i t}$ is a random disturbance term of mean 0 .

While $\mu_{i t}$ is not estimable with $\mathrm{N}=n \times T$ data points, a number of assumptions (restrictions) are usually made, the most common being parameter homogeneity, which means $\alpha_{i t}=\alpha$, for all $i, t$ and $\beta_{i t}=\beta$, for all $i, t$. The resulting model is standard linear pooling for all the data across $i$ and $T$ (see Equation (6)):

$$
y_{i t}=\alpha+\beta x_{i t}+\mu_{i t}
$$

To model the individual heterogeneity of the individual group (in our model country), the error term is assumed to have two separate components, one of each being specific to the individual (country), which does not change over time. The model is named the unobserved effects model, as shown in Equation (7):

$$
y_{i t}=\alpha+\beta x_{i t}+\mu_{i}+\varepsilon_{i t}
$$

There also may be time effects modeled (a symmetric case, Equation (8)), or both, so that the error has three components (explained in Equation (9)):

$$
\begin{gathered}
y_{i t}=\alpha+\beta x_{i t}+\tau_{t}+\varepsilon_{i t} \\
y_{i t}=\alpha+\beta x_{i t}+\mu_{i}+\tau_{t}+\varepsilon_{i t}
\end{gathered}
$$

The appropriate estimation method for these models depends on the properties of the two error components. The idiosyncratic error $\varepsilon_{i t}$ is usually assumed to be independent of both the regressors $x_{i t}$ and the individual error component $\mu_{i}$. The latest (the individual component) may be independent of the regressors $x_{i t}$ or correlated with them.

In the first case (when $\mu_{i}$ is correlated with the regressors $x_{i t}$ ), the ordinary least squares (OLS) estimator would be inconsistent, so $\mu_{i}$ is handled as a further set of $n$ parameters to be estimated. This model is called the fixed effects (a.k.a. within or least squares dummy variables) model, being usually estimated by OLS applied on transformed data (using demeaning), which gives consistent estimates for $\beta$.

In the second case (if the individual-specific component $\mu_{i}$ is uncorrelated with the regressors $x_{i t}$ ), the model is usually identified as the random effects model. In this instance, the overall error $\mu_{i}+\varepsilon_{i t}$ is also uncorrelated with the regressors $x_{i t}$, so that the OLS estimator is consistent. The common error component over individuals induces correlation across the composite error terms, making OLS estimation inefficient, so that the form of feasible generalized least squares (GLS) estimators are used [56].

The choice between the above models (fixed and random effects) are based on Hausman-type tests or the Mundlak approach [57]. The Hausman test [58], which is usually used in the literature, compares the two estimators under the null of no significant difference: if this is not rejected, the more efficient random effects estimator is chosen. 


\subsection{The Econometric Model}

The main objective of the paper is to identify the effect of using ICT infrastructure, using four variables as proxies, on economic growth (EG), while controlling for the macroeconomic environment (CME), employing seven variables as a proxy.

The main purpose is to empirically test the following null hypothesis that there is no relationship between Internet and communications technology and economic growth. The alternative hypothesis is that there is a positive relationship between Internet and communications technology and economic growth.

The following general linear regression model for panel data is considered:

$$
E G_{i, t}=\alpha+\beta_{1} I C T_{j, i, t}+\beta_{2} C M E_{k, i, t}+\mu_{i}+\epsilon_{i, t}
$$

Our model takes into considerations 12 variables: one dependent variable, four interest variables, and seven control variables, explained as follows.

The dependent variable $E G_{i, t}$ is represented by GDP per capita (US dollars at current prices and PPPs), being used as proxy for the effect of using ICT infrastructure on economic growth (coded in models as $\ln g d p$ ).

Our variables of interest, which measure the $I C T_{j, i, t}$, development in country $i$ at time $t$, for $j=1, \ldots, 4$, are:

(1) fixed-broadband subscriptions per 100 inhabitants ( $\operatorname{lnfbs} 100)$, for $j=1$;

(2) the percentage of households with a broadband Internet connection via home computer (hbccp), for $j=2$;

(3) the percentage of individuals using the Internet (lniuip), for $j=3$;

(4) mobile cellular subscriptions per 100 people (lnmcs100), for $j=4$ (see details on the selected variables and the sources of data in Table 1).

The control variables, used as a proxy for the macroeconomic development (CME) of country $i$, at time $t$, for $k=1, \ldots, 7$ are:

(5) gross domestic fixed capital formation, percentage of GDP (lngdfcfpgdp), for $k=1$;

(6) inflation rate, expressed as annual average change (lninf), for $k=2$;

(7) unemployment rate, expressed as annual average (lnunimpl) for $k=3$;

(8) trade openness, expressed as the sum of exports and imports of goods and services measured as a share of gross domestic product in percentage (lnto), for $k=4$;

(9) foreign direct investment, as net inflows, percentage of GDP (lnfdipgdp), for $k=5$;

(10) general government final consumption expenditure, percentage of GDP (lnggfcepgdp), for $k=6$;

(11) financial development is calculated using the domestic credit to private sector as percentage of GDP, for $k=7$.

The estimated, $\beta_{1}$ and $\beta_{2}$ are vectors that incorporate the coefficients from the equations related to our four ICT interest variables.

In all coded variables, we used the $\ln$ prefix, suggesting that values were transformed using the natural logarithm. The choice regarding the use of logarithm is based on the studies of Sassi and Goaied [38], Pradhan et al. [40], Haftu [44], Pradhan et al. [4], and Sepehrdoust [5].

Because reverse-causality and endogeneity could also influence the results, we tested some instrumental variables, and performed regressions with lagged possible endogenous ones, finding that our results remained robust. In this respect, the dynamic panel model are presented as follows.

The GMM (generalized method of moments) is mainly used in panel data econometrics to estimate a dynamic model with the following equation [51]:

$$
y_{i t}=\rho y_{i t-1}+\beta x_{i t}+\mu_{i}+\varepsilon_{i t}
$$


To control for individual effects, the equation is first differenced:

$$
\Delta y_{i t}=\rho \Delta y_{i t-1}+\beta \Delta x_{i t}+\Delta \epsilon_{i t}
$$

Due to the correlation between $\Delta \epsilon_{i t}$ and $\Delta y_{i t-1}$, least squares are inconsistent, while $y_{i t-2}$ is a valid, but weak instrument. The GMM estimator uses the fact that the number of valid instruments is growing with $t$ [51], using a $W_{i}$ matrix:

$$
W_{i}=\left(\begin{array}{ccccccccc}
y_{1} & 0 & 0 & 0 & 0 & 0 & \ldots & 0 & x_{i 3} \\
0 & y_{1} & y_{2} & 0 & 0 & 0 & \ldots & 0 & x_{i 4} \\
0 & 0 & 0 & y_{1} & y_{2} & y_{3} & \ldots & 0 & x_{i 5} \\
\vdots & \vdots & \vdots & \vdots & \vdots & \vdots & \vdots & \vdots & \vdots \\
0 & 0 & 0 & 0 & 0 & 0 & \ldots & y_{t-2} & x_{i T-2}
\end{array}\right)
$$

Regarding the tests implied, the Arellano-Bond test for zero autocorrelation in first-differenced errors is usually used to test for serial correlation (with H0: no autocorrelation). The rejection of autocorrelation of order 1 and not of order 2 is evidence that the Arellano-Bond model assumptions are satisfied. In order to solve the overidentification problem, Roodman $[59,60]$ proposed mechanisms to adequately test the existence of excess of instruments, through the Sargan and Hansen tests.

\section{Results and Discussion}

\subsection{Prelimnary Tests}

To select the model that best describe the effect of using ICT infrastructure on economic growth, we have checked the regression assumptions and have performed several tests suggested by econometric literature [61]. For all tests conducted, the tables with results are available on demand.

Test for poolability of the data (presence of individual effects): we used the F-test that shows that we should reject the null, so the OLS estimates suffer from an omission variables problem, and they are biased and inconsistent (for all equations, in F-test, all the $u_{-} i=0$ the calculated probability was Prob $>\mathrm{F}=0.0000$, the values being extracted from fixed-effect models).

Our data refers to many cross-sectional units (28 countries), which have different structures (different law, tradition, currencies, social and cultural values, and so on), this being a guaranteed to heterogeneity in panel data. That the Lagrange multiplier (LM) test for random effects [62], having null $\mathrm{H}_{0}$ : variance of the unobserved fixed effects, is not statistically different from zero was rejected (Prob $>$ chibar squared $=0$, for all equations involved), so that pooled OLS was not appropriate.

As there could be a deviation from homoscedastic errors in the context of pooled cross-section time-series on panel data (the error process could be homoscedastic within cross-sectional units, but its variance differs across units), the groupwise heteroscedasticity may appear. The Wald statistic for groupwise heteroscedasticity in the residuals of a fixed-effect regression model performed for all equations had zero values for Prob > chi squared, so errors are heteroscedastic. To decide between fixed (FE) and random effects (RE), we used the Hausman test, and the investigation suggested that fixed effects models are appropriate. We have reported the results using Driscoll and Kraay standard errors for linear panel models [63], which are heteroscedasticity consistent and robust to very general forms of cross-sectional and temporal dependence.

\subsection{Descriptive Statistics and Correlation Analysis}

Table 2 shows the basic descriptive statistics by country for the raw data. The descriptive statistics for the logarithmic form are presented in Appendix A, Table A1. There was a wide dispersion within the sample regarding the level of GDP per capita at market prices: the lowest level of GDP per capita was $\$ 5879.08$ for Romania in 2000 , and the highest one was $\$ 102,553.9$ for Luxembourg in 2015 . We also noticed a large cross-country variation in the proxies for ICT infrastructure. The fixed-broadband 
subscriptions per 100 inhabitants (FBS100) ranged from 0.0119\% (Latvia, 2000) to 42.74\% (France, 2016), with a mean of $18.69 \%$. The percentage of households with a broadband Internet connection via home computer ranged (HBCCP) from 1\% (Greece, 2004) to 100\% in many EU countries (Luxembourg, Malta, Austria, Slovenia, and Cyprus) in 2016, with a mean of 79.65\%. In the panel data, the minimum level of the percentage of individuals using the Internet (IUIP) was registered in Romania in $2000(3.61 \%)$ while the highest was in Luxembourg in 2016 (98.13\%). Similar variation existed in the level of mobile cellular subscriptions per 100 people (MCS100)—the lowest level was recorded in Bulgaria $(9.22 \%$ in 2000), while the highest was recorded in Finland in 2012 (172.17\%).

Based on raw data, we applied logarithmic function to all variables. The summary statistics based on logarithmic form shows lower levels of skewness and kurtosis, suggesting no problems regarding normality of data, with the full results being presented in Appendix A (see Table A1).

Table 2. Summary statistics.

\begin{tabular}{cccccccc}
\hline Variable & N & MEAN & SD & MIN & MAX & SKEW & KURTOSIS \\
\hline GDP & 476 & $30,322.74$ & $14,624.91$ & 5879.08 & $102,553.86$ & 1.76 & 5.72 \\
FBS100 & 455 & 18.69 & 12.06 & 0.01 & 42.74 & -0.06 & -1.13 \\
HBCCP & 362 & 79.65 & 24.38 & 1.00 & 100.00 & -1.44 & 1.12 \\
IUIP & 476 & 57.29 & 24.06 & 3.61 & 98.14 & -0.39 & -0.87 \\
MCS100 & 476 & 104.07 & 31.15 & 9.23 & 172.18 & -0.67 & 0.38 \\
GDFCFPGDP & 476 & 22.25 & 4.06 & 11.52 & 38.40 & 0.65 & 1.39 \\
INF & 476 & 2.71 & 3.54 & -1.70 & 45.70 & 6.11 & 60.10 \\
UNIMPL & 476 & 9.04 & 4.37 & 1.90 & 27.50 & 1.46 & 2.39 \\
TO & 476 & 114.66 & 63.23 & 45.61 & 410.17 & 1.91 & 4.34 \\
FDIPGDP & 472 & 10.97 & 37.22 & -58.32 & 451.72 & 8.05 & 76.35 \\
GGFCEPGDP & 476 & 19.78 & 2.77 & 12.34 & 27.93 & 0.53 & 0.11 \\
FD & 417 & 90.19 & 46.34 & 0.19 & 253.26 & 0.91 & 0.96 \\
\hline
\end{tabular}

Source: authors' calculations using the data provided by International Telecommunications Union (ITU), OECD database, World Bank Data Bank, and Eurostat.

The check for correlation across the regressors (to exclude strongly correlated variables) suggested no trouble (correlation coefficients were found to be below 0.8 , as suggested by econometric studies). Table 3 contains the correlation coefficients between the dependent and independent variables. With one exception, the coefficients were quite low, indicating that multicollinearity was unlikely to be a problem in our estimations. In particular, we noted that, consistent with our expectations, GDP was positively associated with all proxies for IC\&T. Thus, increases in these proxies for IC\&T lead to higher GDP. Further investigation refers to the presence of multicollinearity, by computing the variance inflation factors (VIFs), the result being below the threshold of 5 (the mean VIF was calculated to 1.44 to 1.49$)$.

Table 3. Correlation matrix-Pearson coefficients.

\begin{tabular}{|c|c|c|c|c|c|c|c|c|c|c|c|c|}
\hline & 1 & 2 & 3 & 4 & 5 & 6 & 7 & 8 & 9 & 10 & 11 & 12 \\
\hline LNGDP (1) & 1 & & & & & & & & & & & \\
\hline LNFBS100 (2) & 0.59 & 1 & & & & & & & & & & \\
\hline LNHBCCP (3) & 0.26 & 0.82 & 1 & & & & & & & & & \\
\hline LNIUIP (4) & 0.71 & 0.89 & 0.64 & 1 & & & & & & & & \\
\hline LNMCS100 (5) & 0.59 & 0.83 & 0.6 & 0.81 & 1 & & & & & & & \\
\hline LNGDFCFPGDP (6) & -0.32 & -0.29 & -0.3 & -0.28 & -0.17 & 1 & & & & & & \\
\hline LNINF (7) & -0.45 & -0.35 & -0.27 & -0.45 & -0.31 & 0.36 & 1 & & & & & \\
\hline LNUNIMPL (8) & -0.42 & -0.04 & 0.16 & -0.14 & -0.17 & -0.17 & 0 & 1 & & & & \\
\hline LNTO (9) & 0.14 & 0.17 & 0.13 & 0.22 & 0.16 & 0.04 & -0.02 & -0.24 & 1 & & & \\
\hline LNFDIPGDP (10) & 0.01 & -0.04 & -0.04 & -0.01 & -0.08 & 0.11 & 0.16 & -0.24 & 0.57 & 1 & & \\
\hline LNGGFCEPGDP (11) & 0.28 & 0.23 & 0.18 & 0.28 & 0.05 & -0.11 & -0.26 & -0.01 & -0.21 & -0.16 & 1 & \\
\hline LNFD (12) & 0.62 & 0.34 & 0.12 & 0.41 & 0.26 & -0.32 & -0.21 & -0.17 & -0.14 & 0.01 & 0.26 & 1 \\
\hline
\end{tabular}




\subsection{Empirical Results}

Based on Equation (10), we have developed four models, one for every ICT variable of interest. In this approach, $\alpha, \beta_{1}$, and $\beta_{2}$ are vectors that incorporate the coefficients $C(j)$ of each one of the four equations $(j=1, \ldots, 4)$, as follows:

$\alpha=\left\{c(1)_{j, j=1, \ldots 4}\right\}$, the constant value from equations;

$\beta_{1}=\left\{c(2)_{j, j=1, . .4}\right\}$, the coefficients for every interest $I C T_{j}$ variable;

$\beta_{2}=\left\{c(3)_{j}, c(4)_{j}, c(5)_{j}, c(6)_{j}, c(7)_{j}, c(8)_{j}, c(9)_{j}, j=1, \ldots 4\right\}$, the coefficients for every control variable; $C M E_{k, k=1} \ldots 7$, variables, added in equations to every ICT $T_{j}$ variable.

The coefficients were calculated, controlling for the time-invariant effects of country $i$, using OLS with quasi-demeaning values, as Croissant and Millo [56] explained: "The estimation methods for the basic models in panel data econometrics, the pooled OLS, random effects and fixed effects (or within) models, can all be described inside the OLS estimation framework. In fact, while pooled OLS simply pools data, the standard way of estimating fixed models with, say, group (time) effects entails transforming the data by subtracting the average over time (group) to every variable, which is usually termed time-demeaning".

Regarding the construction of our model (based on Equation (10)) and codification for our variables, the estimated four equations for the panel data fixed effects model are:

$$
\begin{aligned}
& \operatorname{lngdp}=c(1)+c(2) \times \operatorname{lnfbs} 100+c(3) \times \operatorname{lngdfcfpgdp}+\mathrm{c}(4) \times \operatorname{lninf}+\mathrm{c}(5) \times \operatorname{lnunimpl}+\mathrm{c}(6) \times \ln \text { to } \\
& +c(7) \times \operatorname{lnfdipgd} p+c(8) \times \operatorname{lnggfcepgd}+c(9) \times \operatorname{lnfd}
\end{aligned}
$$

$$
\begin{gathered}
\operatorname{lngdp}=c(1)+c(2) \times \operatorname{lnhbccp}+c(3) \times \operatorname{lngdfcfpgdp}+c(4) \times \operatorname{lninf}+c(5) \times \ln u \operatorname{limpl}+c(6) \times \operatorname{lnto}+ \\
c(7) \times \operatorname{lnfdipgdp}+c(8) \times \operatorname{lnggfcepgdp}+c(9) \times \operatorname{lnfd}
\end{gathered}
$$

$$
\begin{gathered}
\operatorname{lngdp}=c(1)+c(2) \times \operatorname{lniuip}+c(3) \times \operatorname{lngdf} c f \text { gdp }+c(4) \times \operatorname{lninf}+c(5) \times \operatorname{lnunimpl}+c(6) \times \operatorname{lnto}+ \\
\quad c(7) \times \operatorname{lnfdipgd} p+c(8) \times \operatorname{lnggfcepgdp}+c(9) \times \operatorname{lnfd}
\end{gathered}
$$

$$
\begin{gathered}
\operatorname{lngdp}=c(1)+c(2) \times \operatorname{lnm} c s 100+c(3) \times \operatorname{lngdfcfpgdp}+c(4) \times \operatorname{lninf}+c(5) \times \ln u n i m p l+c(6) \times \ln t o \\
+c(7) \times \operatorname{lnfdipgdp}+c(8) \times \operatorname{lnggfcepgdp}+c(9) \times \operatorname{lnfd}
\end{gathered}
$$

Table A2 (see Appendix A) presents the results for the first estimation where fixed-broadband subscriptions per 100 inhabitants (FBS100) is used as a proxy for the ICT infrastructure. We opted for a step-by-step analysis by adding control variables one by one into the model. In order to conserve space, only the last estimation comprising all the control variables is presented in Table 4, column 1. The coefficient for the ICT variable $\left(\beta_{1}\right)$ was positive and statistically significant at the $1 \%$ level. Thus, the results do not reject the research hypothesis, suggesting a positive and highly significant impact of ICT infrastructure on economic growth, but with the magnitude of the impact being different, depending on the type of technology examined. Thus, the estimated ICT infrastructure coefficients range from 0.0767 (in the case of fixed-broadband subscriptions) to 0.396 (mobile cellular subscriptions). Our findings are in line with the results of other empirical studies $[5,14,24,25,27,35,41,43,64]$. We also point out that the positive and strong impact of ICT infrastructure on economic growth is also found in the conditions in which we have analyzed each type of technology separately (see Appendix A, Tables A2-A5) and have calculated first-difference models (see Appendix A, Table A6). 
Table 4. The impact of using ICT infrastructure on economic growth (the fixed effects model).

\begin{tabular}{|c|c|c|c|c|}
\hline \multirow{3}{*}{ Variables } & (1) & (2) & (3) & (4) \\
\hline & \multicolumn{4}{|c|}{ Model: Fixed Effects } \\
\hline & \multicolumn{4}{|c|}{ Dependent Variable: LNGDP } \\
\hline LNFBS100 & $\begin{array}{c}0.0767^{* * *} \\
(0.0119)\end{array}$ & & & \\
\hline LNHBCCP & & $\begin{array}{l}0.130^{* * *} \\
(0.0241)\end{array}$ & & \\
\hline LNIUIP & & & $\begin{array}{l}0.289 * * * \\
(0.0319)\end{array}$ & \\
\hline LNMCS100 & & & & $\begin{array}{l}0.396^{* * *} \\
(0.0298)\end{array}$ \\
\hline LNGDFCFPGDP & $\begin{array}{l}0.0300 \\
(0.101)\end{array}$ & $\begin{array}{l}-0.0757 \\
(0.0564)\end{array}$ & $\begin{array}{c}0.0865 \\
(0.0926)\end{array}$ & $\begin{array}{l}-0.141 * \\
(0.0673)\end{array}$ \\
\hline LNINF & $\begin{array}{c}-0.0396^{* * *} \\
(0.00922)\end{array}$ & $\begin{array}{c}-0.0361^{* * *} \\
(0.00787)\end{array}$ & $\begin{array}{c}-0.0305^{* * *} \\
(0.00956)\end{array}$ & $\begin{array}{c}-0.0347^{* * *} \\
(0.0104)\end{array}$ \\
\hline LNUNIMPL & $\begin{array}{c}-0.124^{* * *} \\
(0.0375)\end{array}$ & $\begin{array}{c}-0.181 \text { *** } \\
(0.0226)\end{array}$ & $\begin{array}{c}-0.117^{* *} \\
(0.0439)\end{array}$ & $\begin{array}{c}-0.0936 \text { * } \\
(0.0489)\end{array}$ \\
\hline LNTO & $\begin{array}{l}0.645^{* * *} \\
(0.0815)\end{array}$ & $\begin{array}{l}0.686^{* * *} \\
(0.0827)\end{array}$ & $\begin{array}{l}0.475 * * * \\
(0.0877)\end{array}$ & $\begin{array}{l}0.498^{* * *} \\
(0.0803)\end{array}$ \\
\hline LNFDIPGDP & $\begin{array}{c}-0.0276^{* * *} \\
(0.00821)\end{array}$ & $\begin{array}{c}-0.0287^{* * *} \\
(0.00733)\end{array}$ & $\begin{array}{c}-0.0246^{* * *} \\
(0.00664)\end{array}$ & $\begin{array}{c}-0.0237^{* * * *} \\
(0.00561)\end{array}$ \\
\hline LNGGFCEPGDP & $\begin{array}{l}0.232 * * \\
(0.107)\end{array}$ & $\begin{array}{l}0.241 * \\
(0.135)\end{array}$ & $\begin{array}{c}0.433^{* * *} \\
(0.121)\end{array}$ & $\begin{array}{c}0.349^{* * *} \\
(0.115)\end{array}$ \\
\hline LNFD & $\begin{array}{c}0.0653 \\
(0.0484)\end{array}$ & $\begin{array}{c}0.0729 \\
(0.0499)\end{array}$ & $\begin{array}{c}0.0142 \\
(0.0575)\end{array}$ & $\begin{array}{c}0.0256 \\
(0.0635)\end{array}$ \\
\hline Constant & $\begin{array}{c}6.359^{* * * *} \\
(0.824)\end{array}$ & $\begin{array}{c}6.198^{* * *} \\
(0.772)\end{array}$ & $\begin{array}{c}5.596^{* * * *} \\
(0.806)\end{array}$ & $\begin{array}{c}5.660^{* * *} \\
(0.568)\end{array}$ \\
\hline Observations & 336 & 277 & 345 & 345 \\
\hline Number of groups & 28 & 28 & 28 & 28 \\
\hline Unit effects Country & YES & YES & YES & YES \\
\hline Robust Kraay-Driscoll & YES & YES & YES & YES \\
\hline
\end{tabular}

Note: standard errors between parentheses; ${ }^{*}, * *$, and ${ }^{* * *}$ indicate significance at $10 \%, 5 \%$, and $1 \%$ levels, respectively. Source: own calculations.

In order to test the robustness of our findings, we employed three other proxies for ICT infrastructure: the percentage of households with a broadband Internet connection via home computer range (HBCCP), the level of the percentage of individuals using the Internet (IUIP), and the level of mobile cellular subscriptions per 100 people (MCS100). The results for the these models employing alternative measures for IC\&T infrastructure (see Table 4, columns 2, 3, and 4) are broadly in line with those obtained for the first model. The coefficient for the ICT variable $\left(\beta_{1}\right)$ is positive and statistically significant at the $1 \%$ level for all models considered. These results indicate that ICT infrastructure can contribute to the increase per capita economic growth. The highest magnitude of this impact was recorded for the level of mobile cellular subscriptions, suggesting that a $1 \%$ increase in mobile cellular subscriptions would determine an increase of $0.396 \%$ GDP per capita across the 28 EU countries.

Regarding the macroeconomic control variables, we found that almost all, except for financial development and gross domestic fixed capital formation, had a significant effect on economic growth in all four models presented in Table 4. The estimated coefficients of the inflation rate (LNINF) were all negative and significant at a $1 \%$ level. These results indicate a negative and strongly significant relationship with GDP per capita, in line with the findings of Choi and Yi [24], Sassi 
and Goaied [38], Haftu [44], Pradhan et al. [4], and Sepehrdoust [5]. A low level of inflation will lower the cost of production in real terms, which will positively affect per capita economic growth. Also, the unemployment rate (LNUNIMPL) was negatively and significantly associated with economic growth, in line with the theoretical predictions, according to which the reduction of the unemployment rate would lead to the improvement of the economic growth. Regarding the degree of trade openness (LNTO), all estimated coefficients were positive and significant at $1 \%$, so that we find that this indicator is positively and very strongly associated with GDP per capita. Therefore, we can affirm that trade openness is a key driver of economic growth in EU countries. Our results are in line with the previous findings of Czernich et al. [23], Sassi and Goaied [38], Pradhan et al. [40], and Latif et al. [45]. According to Hodrab et al. [64], the positive effect of this variable on economic growth results from the fact that increased production for exports and the increase in imports availability in local markets will stimulate local firms that are facing the pressure of competitiveness to innovate new efficient production methods, or to adopt new technologies, that will lead to increased productivity and lower cost of production, and this fact will be reflected positively on economic growth.

The coefficient on foreign direct investment (LNFDIPGDP) is negative and significant the $1 \%$ significance level in all four estimates presented in Table 4 , which implies that FDI would have a negative and profound effect on GDP per capita. Surprisingly, our results do not reflect the theoretical predictions that FDI would be one of the main factors of economic growth, but they are in line with the findings of several empirical studies [65]. The negative effect of FDI on economic growth (which in all analyzed countries ranges from -0.0237 to -0.0287 ) could be recorded when many foreign investors repatriate the profit, but also when the domestic firms do not cope with competition with foreign firms and are forced to leave the market [66].

Government expenditures (LNGGFCEPGDP) are positive and significantly associated with GDP per capita, in agreement with the results obtained by Sepehrdoust [5]. The positive relationship between government expenditures and economic growth can be explained by the fact that increasing the expenditures of government within society can lead to improving economic growth.

With regard to the gross fixed capital formation variable (LNGDFCFPGDP), our results show a positive (in line with the findings of Nasab and Aghaei [27], Vu [14], Pradhan et al. [40], and Haftu [44]), but insignificant impact on GDP per capita, similar to the results of Sepehrdoust [5] (if we measure ICT infrastructure through LNFBS100 and LNIUIP). On the other hand, we found a negative association of this variable with economic growth for the other two indicators of ICT infrastructure (see columns 2 and 4 from Table 4).

In the case of the financial development variable, many theoretical studies have discussed its positive effect on economic growth, and they have underlined that this variable would be one of the most important determinants of economic growth. Our empirical estimates reveal that all financial development coefficients (LNFD) are positive, but insignificant at any of the significance levels. Therefore, for our entire panel of countries, financial development does not appear to significantly affect GDP per capita. One possible explanation would be that we considered as a proxy measure of financial development only the ratio of domestic credit to the private sector as share of the GDP, because in EU countries, the financing of the real economy is largely focused on the credits granted by the financial institutions, especially banking credit. However, the financial development dimension is also given by the total value of stocks traded as a share of GDP. Compared to our results, and with reference to other country panels, some studies $[5,25,32,41,67]$ found a positive and significant relationship between financial development and economic growth.

Our empirical results regarding the effect of the above-mentioned control macroeconomic variables on GDP per capita are similar to those found when we separately investigated the impact of each of the four ICT infrastructure indicators (see Appendix A). 
We also test the robustness of our findings by employing an alternative methodology-FD-GMM estimation method. The estimated four equations for dynamic panel data model are:

$$
\begin{aligned}
\operatorname{lngdp}= & c(1) \times(\operatorname{lngdp}(-1))+c(2) \times \operatorname{lnfbs} 100+c(3) \times \operatorname{lnunimpl}+c(4) \times \operatorname{lninf}+c(5) \times \operatorname{lnfd}+ \\
& c(6) \times \operatorname{lnfdipgdp}+c(7) \times \operatorname{lngdfcfpgdp}+c(8) \times \operatorname{lng} g f c e p g d p+c(9) \times \ln \text { to }
\end{aligned}
$$

$$
\begin{aligned}
& \operatorname{lngdp}=c(1) \times(\operatorname{lngdp}(-1))+c(2) \times \operatorname{lnm} c s 100+c(3) \times \operatorname{lnunimpl}+c(4) \times \operatorname{lninf}+c(5) \times \operatorname{lnfd}+ \\
& c(6) \times \operatorname{lnfdipgdp}+c(7) \times \operatorname{lngdfcfpgdp}+c(8) \times \operatorname{lnggfcepgdp}+c(9) \times \ln \text { to } \\
& \operatorname{lngdp}=c(1) \times(\operatorname{lngdp}(-1))+c(2) \times \operatorname{lnhbccp}+c(3) \times \ln u \operatorname{nimpl}+\mathrm{c}(4) \times \operatorname{lninf}+c(5) \times \operatorname{lnfd}+ \\
& c(6) \times \operatorname{lnfdipgdp}+c(7) \times \operatorname{lngdfcfpgdp}+c(8) \times \operatorname{lnggfcepgdp}+c(9) \times \ln \text { to } \\
& \operatorname{lngdp}=c(1) \times(\operatorname{lngdp}(-1))+c(2) \times \operatorname{lniuip}+c(3) \times \operatorname{lnunimpl}+\mathrm{c}(4) \times \operatorname{lninf}+\mathrm{c}(5) \times \operatorname{lnfd}+ \\
& c(6) \times \operatorname{lnfdipgdp}+c(7) \times \operatorname{lngdfcfpgdp}+\mathrm{c}(8) \times \operatorname{lnggfcepgdp}+\mathrm{c}(9) \times \ln \text { to }
\end{aligned}
$$

The same as explained above (for fixed-effects model), $\beta_{1}$ and $\beta_{2}$ are vectors that incorporate the

\begin{tabular}{|c|c|c|c|c|}
\hline Equation Name: & EQ01 & EQ02 & EQ03 & EQ04 \\
\hline Dependent Variable & LNGDP & LNGDP & LNGDP & LNGDP \\
\hline LNGDP(-1) & $\begin{array}{c}0.662762 * * * \\
(0.0382)\end{array}$ & $\begin{array}{c}0.684954^{* * *} \\
(0.0379)\end{array}$ & $\begin{array}{c}0.773796^{* * *} \\
(0.0598)\end{array}$ & $\begin{array}{c}0.683272 * * * \\
(0.0236)\end{array}$ \\
\hline LNFBS100 & $\begin{array}{c}0.019879 * * * \\
(0.0056)\end{array}$ & & & \\
\hline LNMCS100 & & $\begin{array}{c}0.070348^{* *} \\
(0.0305)\end{array}$ & & \\
\hline LNHBCCP & & & $\begin{array}{c}0.015653^{* *} \\
(0.0148)\end{array}$ & \\
\hline LNIUIP & & & & $\begin{array}{c}0.065012^{* * * *} \\
(0.0086)\end{array}$ \\
\hline LNUNIMPL & $\begin{array}{c}-0.040035 \\
(0.0220)\end{array}$ & $\begin{array}{c}-0.034963 \\
(0.0327)\end{array}$ & $\begin{array}{c}-0.019518 \\
(0.0292)\end{array}$ & $\begin{array}{c}-0.037311 \\
(0.0356)\end{array}$ \\
\hline LNINF & $\begin{array}{c}-0.000737 \\
(0.0035)\end{array}$ & $\begin{array}{c}-0.003933 \\
(0.0036)\end{array}$ & $\begin{array}{c}0.000052 \\
(0.0054)\end{array}$ & $\begin{array}{c}-0.000712 \\
(0.0043)\end{array}$ \\
\hline LNFD & $\begin{array}{c}0.037038^{* *} \\
(0.0185)\end{array}$ & $\begin{array}{c}0.059001 \text { ** } \\
(0.0295)\end{array}$ & $\begin{array}{c}0.009450 \\
(0.0296)\end{array}$ & $\begin{array}{c}0.036234^{* *} \\
(0.0167)\end{array}$ \\
\hline LNFDIPGDP & $\begin{array}{c}-0.008939 \\
(0.0059)\end{array}$ & $\begin{array}{c}-0.002793 \\
(0.0084)\end{array}$ & $\begin{array}{c}0.004015 \\
(0.0063)\end{array}$ & $\begin{array}{c}-0.008823 \\
(0.0087)\end{array}$ \\
\hline LNGDFCFPGDP & $\begin{array}{c}0.009798 \\
(0.0854)\end{array}$ & $\begin{array}{c}0.013995 \\
(0.0640)\end{array}$ & $\begin{array}{c}0.102381 \\
(0.0656)\end{array}$ & $\begin{array}{c}0.083748 \\
(0.0638)\end{array}$ \\
\hline LNGGFCEPGDP & $\begin{array}{c}-0.156467 \\
(0.0789)\end{array}$ & $\begin{array}{c}-0.131311 \\
(0.0686)\end{array}$ & $\begin{array}{c}-0.062402 \\
(0.0799)\end{array}$ & $\begin{array}{c}-0.143762 \text { ** } \\
(0.0682)\end{array}$ \\
\hline LNTO & $\begin{array}{c}0.290580^{* * *} \\
(0.0483)\end{array}$ & $\begin{array}{c}0.291228 * * * \\
(0.0409)\end{array}$ & $\begin{array}{c}0.269596^{* * *} \\
(0.0456)\end{array}$ & $\begin{array}{c}0.296422 * * * \\
(0.0355)\end{array}$ \\
\hline Observations: & 307 & 315 & 249 & 315 \\
\hline
\end{tabular}
coefficients of the Equations (18) to (21), coded $C(j)$, as follows:

$\rho=\left\{c(1)_{j, j=1, \ldots 4}\right\}$, the coefficient value for a lagged dependent variable;

$\beta_{1}=\left\{c(2)_{j, j=1, \ldots 4}\right\}$, the coefficients for every interest of $I C T_{j}$ variables;

$\beta_{2}=\left\{c(3)_{j}, c(4)_{j}, c(5)_{j}, c(6)_{j}, c(7)_{j}, c(8)_{j}, c(9)_{j}, j=1, \ldots 4\right\}$, the coefficients for every interest;

$C M E_{k, k=1} \ldots 7$ variables, related to every $I C T_{j}$ variables.

The results are presented in Table 5 for all indicators used as proxies for ICT infrastructure.

Table 5. The impact of using ICT infrastructure on economic growth (FD-GMM).

Note: standard errors between parentheses; ${ }^{* *}$, and ${ }^{* * *}$ indicate significance at $10 \%, 5 \%$, and $1 \%$ levels, respectively. Source: own calculations. 


\section{Conclusions}

This study aimed to analyze and evaluate empirically the effect of using ICT infrastructure on economic growth in EU countries for a period of 18 years (2000-2017). Using panel-data estimation, we have examined empirically how various indicators of ICT infrastructure affect economic growth, proxied in our study by GDP per capita. In our analysis, we have also included seven macroeconomic control variables, namely: gross fixed capital formation, inflation rate, unemployment rate, trade openness, inflows of foreign direct investment, general government final consumption expenditure, and the level of financial development.

Our empirical estimates indicate a positive and highly significant impact of ICT infrastructure on GDP per capita, but the magnitude of the impact is different depending on the type of technology considered in the analysis. Thus, we find that an increase of $1 \%$ in the use of ICT infrastructure would contribute to a GDP per capita growth between $0.0767 \%$ (fixed-broadband subscriptions) and $0.396 \%$ (mobile cell subscriptions). Likewise, our results reflect a positive and powerful effect of the use of ICT infrastructure on economic growth when we analyze separately each of the four indicators used as proxies for ICT infrastructure.

Regarding the impact of macroeconomic factors, we found that inflation, unemployment rate, the degree of trade openness, government expenditures, and foreign direct investment would significantly affect GDP per capita at the EU level. The findings of the study reveal that ICT infrastructure, along with other macroeconomic factors are important drivers of economic growth in the EU countries.

Based on our research, we emphasize that, in order to promote economic growth, ICT infrastructure development (by encouraging increased investment in ICT so as to provide easy access to these technologies) should be a priority in government policies.

A drawback of our study is limiting the investigation to the EU countries only. Therefore, as a future research direction, we aim to extend the analysis with data for other European non-EU countries, as well as to analyze the impact of ICT use on groups of countries, depending on their level of development, including the assessment of the impact of economic growth on ICT development.

Author Contributions: All authors conceived the study and contributed equally to the writing of the paper.

Funding: This research received no external funding.

Conflicts of Interest: The authors declare no conflict of interest.

\section{Appendix}

Table A1. Summary statistics (logarithmic form).

\begin{tabular}{cccccccc}
\hline & N & Mean & Sd & Min & Max & Skew & Kurtosis \\
\hline LNGDP & 476 & 10.21 & 0.41 & 9.32 & 10.81 & -0.56 & -0.44 \\
LNFBS100 & 455 & 2.42 & 1.36 & -1.18 & 3.63 & -1.48 & 1.09 \\
LNHBCCP & 362 & 4.33 & 0.38 & 3.30 & 4.61 & -1.65 & 1.53 \\
LNIUIP & 476 & 3.93 & 0.53 & 2.61 & 4.51 & -1.10 & 0.28 \\
LNMCS100 & 476 & 4.60 & 0.33 & 3.68 & 5.02 & -1.25 & 1.11 \\
LNGDFCFPGDP & 476 & 3.09 & 0.15 & 2.81 & 3.39 & 0.12 & -0.62 \\
LNINF & 432 & 0.73 & 0.82 & -1.20 & 2.03 & -0.76 & 0.15 \\
LNUNIMPL & 476 & 2.10 & 0.41 & 1.44 & 2.88 & 0.28 & -0.77 \\
LNTO & 476 & 4.62 & 0.44 & 3.96 & 5.59 & 0.39 & -0.59 \\
LNFDIPGDP & 440 & 1.45 & 1.10 & -0.55 & 3.62 & 0.14 & -0.56 \\
LNGGFCEPGDP & 476 & 2.98 & 0.13 & 2.76 & 3.23 & 0.32 & -0.55 \\
LNFD & 417 & 4.37 & 0.49 & 3.38 & 5.16 & -0.30 & -0.76 \\
\hline
\end{tabular}

Source: authors' calculations using the data provided by International Telecommunications Union (ITU), OECD database, World Bank Data Bank, and Eurostat. 
Table A2. The impact of using ICT infrastructure (fixed-broadband subscriptions per 100 inhabitants) on economic growth.

\begin{tabular}{|c|c|c|c|c|c|c|c|c|}
\hline \multirow{3}{*}{ Variables } & (1) & (2) & (3) & (4) & (5) & (6) & (7) & (8) \\
\hline & \multicolumn{8}{|c|}{ Model: Fixed Effects } \\
\hline & \multicolumn{8}{|c|}{ Dependent Variable: lngdp } \\
\hline $\operatorname{lnfbs} 100$ & $\begin{array}{c}0.126^{* * *} \\
(0.0133)\end{array}$ & $\begin{array}{c}0.124 * * * \\
(0.0125)\end{array}$ & $\begin{array}{l}0.117^{* * *} \\
(0.0103)\end{array}$ & $\begin{array}{l}0.113^{* * *} \\
(0.0107)\end{array}$ & $\begin{array}{l}0.0872^{* * *} \\
(0.00772)\end{array}$ & $\begin{array}{c}0.0867 * * * \\
(0.00725)\end{array}$ & $\begin{array}{c}0.0846^{* * *} \\
(0.00712)\end{array}$ & $\begin{array}{c}0.0767^{* * * *} \\
(0.0119)\end{array}$ \\
\hline $\operatorname{lngdfcfpgdp}$ & & $\begin{array}{l}-0.0781 \\
(0.0684)\end{array}$ & $\begin{array}{l}0.00181 \\
(0.0695)\end{array}$ & $\begin{array}{c}-0.305 \\
* * * \\
(0.0896)\end{array}$ & $\begin{array}{c}-0.0999 \\
(0.110)\end{array}$ & $\begin{array}{l}-0.0987 \\
(0.0934)\end{array}$ & $\begin{array}{l}-0.0858 \\
(0.0914)\end{array}$ & $\begin{array}{l}0.0300 \\
(0.101)\end{array}$ \\
\hline Lninf & & & $\begin{array}{c}-0.0423 * \\
(0.0214)\end{array}$ & $\begin{array}{c}-0.0411 \\
* * \\
(0.0191)\end{array}$ & $\begin{array}{c}-0.0369 \\
* * * \\
(0.00881)\end{array}$ & $\begin{array}{c}-0.0309 \\
* * * \\
(0.00826)\end{array}$ & $\begin{array}{c}-0.0315 \\
* * * \\
(0.00807)\end{array}$ & $\begin{array}{c}-0.0396 \\
* * * \\
(0.00922)\end{array}$ \\
\hline Lnunimpl & & & & $\begin{array}{c}-0.188 \\
* * * \\
(0.0325)\end{array}$ & $\begin{array}{c}-0.133 \\
* * * \\
(0.0307)\end{array}$ & $\begin{array}{c}-0.141 \\
* * * \\
(0.0314)\end{array}$ & $\begin{array}{c}-0.147 \\
* * * \\
(0.0329)\end{array}$ & $\begin{array}{c}-0.124 \\
* * * \\
(0.0375)\end{array}$ \\
\hline Lnto & & & & & $\begin{array}{c}0.673^{* * *} \\
(0.113)\end{array}$ & $\begin{array}{c}0.652^{* * * *} \\
(0.105)\end{array}$ & $\begin{array}{c}0.682^{* * *} \\
(0.109)\end{array}$ & $\begin{array}{l}0.645^{* * *} \\
(0.0815)\end{array}$ \\
\hline Lnfdipgdp & & & & & & $\begin{array}{c}-0.0244 \\
* * \\
(0.0108)\end{array}$ & $\begin{array}{c}-0.0237 \\
* * \\
(0.0105)\end{array}$ & $\begin{array}{c}-0.0276 \\
* * * \\
(0.00821)\end{array}$ \\
\hline lnggfcepgdp & & & & & & & $\begin{array}{c}0.131 * \\
(0.0720)\end{array}$ & $\begin{array}{l}0.232 \text { ** } \\
(0.107)\end{array}$ \\
\hline Lnfd & & & & & & & & $\begin{array}{c}0.0653 \\
(0.0484)\end{array}$ \\
\hline Constant & $\begin{array}{l}9.926^{* * *} \\
(0.0292)\end{array}$ & $\begin{array}{c}10.17^{* * *} \\
(0.210)\end{array}$ & $\begin{array}{c}9.974 * * * \\
(0.202)\end{array}$ & $\begin{array}{c}11.32 * * * \\
(0.309)\end{array}$ & $\begin{array}{c}7.522 * * * \\
(0.749)\end{array}$ & $\begin{array}{c}7.662 * * * \\
(0.674)\end{array}$ & $\begin{array}{c}7.111 * * * \\
(0.764)\end{array}$ & $\begin{array}{c}6.359 * * * \\
(0.824)\end{array}$ \\
\hline Observations & 455 & 455 & 411 & 411 & 411 & 379 & 379 & 336 \\
\hline Number of groups & 28 & 28 & 28 & 28 & 28 & 28 & 28 & 28 \\
\hline Unit effects Country & YES & YES & YES & YES & YES & YES & YES & YES \\
\hline Robust Kraay-Driscoll & YES & YES & YES & YES & YES & YES & YES & YES \\
\hline
\end{tabular}

Note: standard errors between parentheses; ${ }^{*}, * *$, and ${ }^{* * *}$ indicate significance at $10 \%, 5 \%$, and $1 \%$ levels, respectively. Source: own calculations.

Table A3. The impact of using ICT infrastructure (broadband Internet connection via home computer) on economic growth.

\begin{tabular}{|c|c|c|c|c|c|c|c|c|}
\hline \multirow{3}{*}{ Variables } & (1) & (2) & (3) & (4) & (5) & (6) & (7) & (8) \\
\hline & \multicolumn{8}{|c|}{ Model: Fixed Effects } \\
\hline & \multicolumn{8}{|c|}{ Dependent Variable: lngdp } \\
\hline $\operatorname{lnhbccp}$ & $\begin{array}{c}0.295^{* * *} \\
(0.0259)\end{array}$ & $\begin{array}{l}0.293 \text { **** } \\
(0.0211)\end{array}$ & $\begin{array}{c}0.276^{* * *} \\
(0.0117)\end{array}$ & $\begin{array}{c}0.257^{* * * *} \\
(0.0168)\end{array}$ & $\begin{array}{c}0.172 * * * \\
(0.0188)\end{array}$ & $\begin{array}{c}0.164 * * * \\
(0.0166)\end{array}$ & $\begin{array}{l}0.155^{* * *} \\
(0.0178)\end{array}$ & $\begin{array}{c}0.130 * * * \\
(0.0241)\end{array}$ \\
\hline lngdfcfpgdp & & $\begin{array}{l}-0.0164 \\
(0.0651)\end{array}$ & $\begin{array}{c}0.0859 \\
(0.0492)\end{array}$ & $\begin{array}{c}-0.296^{* *} \\
(0.0992)\end{array}$ & $\begin{array}{c}-0.209 * * \\
(0.0867)\end{array}$ & $\begin{array}{c}-0.167^{* *} \\
(0.0717)\end{array}$ & $\begin{array}{c}-0.152 * * \\
(0.0683)\end{array}$ & $\begin{array}{l}-0.0757 \\
(0.0564)\end{array}$ \\
\hline $\operatorname{lninf}$ & & & $\begin{array}{c}-0.0454 \\
* * \\
(0.0179)\end{array}$ & $\begin{array}{c}-0.0394 \\
* * \\
(0.0145)\end{array}$ & $\begin{array}{c}-0.0356 \\
* * * \\
(0.00740)\end{array}$ & $\begin{array}{c}-0.0313 \\
* * * \\
(0.00706)\end{array}$ & $\begin{array}{c}-0.0324 \\
* * * \\
(0.00701)\end{array}$ & $\begin{array}{c}-0.0361 \\
* * * \\
(0.00787)\end{array}$ \\
\hline lnunimpl & & & & $\begin{array}{c}-0.199 \\
* * * \\
(0.0379)\end{array}$ & $\begin{array}{c}-0.184 \\
* * * \\
(0.0242)\end{array}$ & $\begin{array}{c}-0.189 \\
* * * \\
(0.0240)\end{array}$ & $\begin{array}{c}-0.195 \\
* * * \\
(0.0259)\end{array}$ & $\begin{array}{c}-0.181 \\
* * * \\
(0.0226)\end{array}$ \\
\hline lnto & & & & & $\begin{array}{c}0.637^{* * *} \\
(0.121) \\
\end{array}$ & $\begin{array}{c}0.668^{* * * *} \\
(0.108) \\
\end{array}$ & $\begin{array}{c}0.712 * * * \\
(0.110) \\
\end{array}$ & $\begin{array}{c}0.686^{* * *} \\
(0.0827) \\
\end{array}$ \\
\hline lnfdipgdp & & & & & & $\begin{array}{c}-0.0334 \\
* * * \\
(0.00817)\end{array}$ & $\begin{array}{c}-0.0325 \\
* * * \\
(0.00774)\end{array}$ & $\begin{array}{c}-0.0287 \\
* * * \\
(0.00733)\end{array}$ \\
\hline lnggfcepgdp & & & & & & & $\begin{array}{c}0.167^{*} \\
(0.0885)\end{array}$ & $\begin{array}{l}0.241 * \\
(0.135)\end{array}$ \\
\hline $\operatorname{lnfd}$ & & & & & & & & $\begin{array}{c}0.0729 \\
(0.0499)\end{array}$ \\
\hline Constant & $\begin{array}{c}9.023^{* * *} \\
(0.0931)\end{array}$ & $\begin{array}{c}9.084^{* * *} \\
(0.195)\end{array}$ & $\begin{array}{c}8.877^{* * *} \\
(0.151)\end{array}$ & $\begin{array}{c}10.54 * * * \\
(0.399)\end{array}$ & $\begin{array}{c}7.646^{* * *} \\
(0.562)\end{array}$ & $\begin{array}{c}7.449^{* * *} \\
(0.493)\end{array}$ & $\begin{array}{c}6.752 * * * \\
(0.568)\end{array}$ & $\begin{array}{c}6.198^{* * *} \\
(0.772)\end{array}$ \\
\hline Observations & 362 & 362 & 318 & 318 & 318 & 290 & 290 & 277 \\
\hline Number of groups & 28 & 28 & 28 & 28 & 28 & 28 & 28 & 28 \\
\hline Unit effects Country & YES & YES & YES & YES & YES & YES & YES & YES \\
\hline Robust Kraay-Driscoll & YES & YES & YES & YES & YES & YES & YES & YES \\
\hline
\end{tabular}

Note: standard errors between parentheses; ${ }^{*}, * *$, and ${ }^{* * *}$ indicate significance at $10 \%, 5 \%$, and $1 \%$ levels, respectively. Source: own calculations. 
Table A4. The impact of using ICT infrastructure (percentage of individuals using the Internet) on economic growth.

\begin{tabular}{|c|c|c|c|c|c|c|c|c|}
\hline \multirow{3}{*}{ Variables } & (1) & (2) & (3) & (4) & (5) & (6) & (7) & (8) \\
\hline & \multicolumn{8}{|c|}{ Model: Fixed Effects } \\
\hline & \multicolumn{8}{|c|}{ Dependent Variable: lngdp } \\
\hline lniuip & $\begin{array}{l}0.398^{* * *} \\
(0.0325)\end{array}$ & $\begin{array}{l}0.401 * * * \\
(0.0340)\end{array}$ & $\begin{array}{l}0.382^{* * *} \\
(0.0296)\end{array}$ & $\begin{array}{l}0.368^{* * * *} \\
(0.0303)\end{array}$ & $\begin{array}{l}0.302 * * * \\
(0.0183)\end{array}$ & $\begin{array}{l}0.304 * * * \\
(0.0174)\end{array}$ & $\begin{array}{l}0.292 * * * \\
(0.0170)\end{array}$ & $\begin{array}{c}0.289^{* * *} \\
(0.0319)\end{array}$ \\
\hline lngdfcfpgdp & & $\begin{array}{c}0.0286 \\
(0.0555)\end{array}$ & $\begin{array}{c}0.0519 \\
(0.0559)\end{array}$ & $\begin{array}{c}-0.234 \\
* * * \\
(0.0731)\end{array}$ & $\begin{array}{l}-0.121 \\
(0.0778)\end{array}$ & $\begin{array}{l}-0.0987 \\
(0.0731)\end{array}$ & $\begin{array}{l}-0.0597 \\
(0.0770)\end{array}$ & $\begin{array}{c}0.0865 \\
(0.0926)\end{array}$ \\
\hline $\operatorname{lninf}$ & & & $\begin{array}{c}-0.0312 * \\
(0.0173)\end{array}$ & $\begin{array}{c}-0.0312 * \\
(0.0156)\end{array}$ & $\begin{array}{c}-0.0300 \\
* * * \\
(0.00918)\end{array}$ & $\begin{array}{c}-0.0257 \\
* * * \\
(0.00867)\end{array}$ & $\begin{array}{c}-0.0272 \\
* * * \\
(0.00825)\end{array}$ & $\begin{array}{c}-0.0305 \\
* * * \\
(0.00956)\end{array}$ \\
\hline lnunimpl & & & & $\begin{array}{c}-0.181 \\
* * * \\
(0.0322)\end{array}$ & $\begin{array}{c}-0.136 \\
* * * \\
(0.0350)\end{array}$ & $\begin{array}{c}-0.135 \\
* * * \\
(0.0365)\end{array}$ & $\begin{array}{c}-0.148 \\
* * * \\
(0.0365)\end{array}$ & $\begin{array}{c}-0.117^{* *} \\
(0.0439)\end{array}$ \\
\hline lnto & & & & & $\begin{array}{c}0.470^{* * *} \\
(0.109)\end{array}$ & $\begin{array}{c}0.448^{* * * *} \\
(0.110)\end{array}$ & $\begin{array}{c}0.525^{* * *} \\
(0.120)\end{array}$ & $\begin{array}{l}0.475^{* * * *} \\
(0.0877)\end{array}$ \\
\hline lnfdipgdp & & & & & & $\begin{array}{c}-0.0240 \\
* * * \\
(0.00812)\end{array}$ & $\begin{array}{c}-0.0224 \\
* * \\
(0.00774)\end{array}$ & $\begin{array}{c}-0.0246 \\
* * * \\
(0.00664)\end{array}$ \\
\hline lnggfcepgdp & & & & & & & $\begin{array}{l}0.319 * * * \\
(0.0860)\end{array}$ & $\begin{array}{c}0.433^{* * *} \\
(0.121)\end{array}$ \\
\hline $\operatorname{lnfd}$ & & & & & & & & $\begin{array}{c}0.0142 \\
(0.0575)\end{array}$ \\
\hline Constant & $\begin{array}{c}8.639^{* * *} \\
(0.126)\end{array}$ & $\begin{array}{c}8.541 * * * \\
(0.232)\end{array}$ & $\begin{array}{c}8.569^{* * * *} \\
(0.240)\end{array}$ & $\begin{array}{c}9.884^{* * *} \\
(0.283)\end{array}$ & $\begin{array}{c}7.528^{* * *} \\
(0.594)\end{array}$ & $\begin{array}{c}7.575^{* * * *} \\
(0.586)\end{array}$ & $\begin{array}{c}6.226^{* * * *} \\
(0.852)\end{array}$ & $\begin{array}{c}5.596^{* * *} \\
(0.806)\end{array}$ \\
\hline Observations & 476 & 476 & 432 & 432 & 432 & 398 & 398 & 345 \\
\hline Number of groups & 28 & 28 & 28 & 28 & 28 & 28 & 28 & 28 \\
\hline Unit effects Country & YES & YES & YES & YES & YES & YES & YES & YES \\
\hline Robust Kraay-Driscoll & YES & YES & YES & YES & YES & YES & YES & YES \\
\hline
\end{tabular}

Note: standard errors between parentheses; ${ }^{*}, * *$, and ${ }^{* * *}$ indicate significance at $10 \%, 5 \%$, and $1 \%$ levels, respectively. Source: own calculations.

Table A5. The impact of using ICT infrastructure (mobile cellular subscriptions per 100 people) on economic growth.

\begin{tabular}{|c|c|c|c|c|c|c|c|c|}
\hline \multirow{3}{*}{ Variables } & (1) & (2) & (3) & (4) & (5) & (6) & (7) & (8) \\
\hline & \multicolumn{8}{|c|}{ Model: Fixed Effects } \\
\hline & \multicolumn{8}{|c|}{ Dependent Variable: lngdp } \\
\hline lnmes100 & $\begin{array}{l}0.586^{* * * *} \\
(0.0559)\end{array}$ & $\begin{array}{l}0.570 * * * \\
(0.0457)\end{array}$ & $\begin{array}{c}0.536 * * * \\
(0.0312)\end{array}$ & $\begin{array}{l}0.517 * * * \\
(0.0304)\end{array}$ & $\begin{array}{c}0.432 * * * \\
(0.0100)\end{array}$ & $\begin{array}{c}0.436^{* * * *} \\
(0.0112)\end{array}$ & $\begin{array}{l}0.421 * * * \\
(0.00986)\end{array}$ & $\begin{array}{c}0.396^{* * *} \\
(0.0298)\end{array}$ \\
\hline lngdfcfpgdp & & $\begin{array}{c}-0.301 \\
* * * \\
(0.0646) \\
\end{array}$ & $\begin{array}{c}-0.230 \\
* * * \\
(0.0621) \\
\end{array}$ & $\begin{array}{c}-0.418 \\
* * * \\
(0.0563) \\
\end{array}$ & $\begin{array}{c}-0.274 \\
* * * \\
(0.0629) \\
\end{array}$ & $\begin{array}{c}-0.272 \\
* * * \\
(0.0591)\end{array}$ & $\begin{array}{c}-0.231 \\
* * * \\
(0.0649)\end{array}$ & $\begin{array}{l}-0.141 \text { * } \\
(0.0673)\end{array}$ \\
\hline $\operatorname{lninf}$ & & & $\begin{array}{c}-0.0389 \\
* * \\
(0.0167)\end{array}$ & $\begin{array}{c}-0.0393 \\
* * \\
(0.0155)\end{array}$ & $\begin{array}{c}-0.0362 \\
* * * \\
(0.00932)\end{array}$ & $\begin{array}{c}-0.0308 \\
* * * \\
(0.00958)\end{array}$ & $\begin{array}{c}-0.0319 \\
* * * \\
(0.00927)\end{array}$ & $\begin{array}{c}-0.0347 \\
* * * \\
(0.0104)\end{array}$ \\
\hline Inunimpl & & & & $\begin{array}{c}-0.123 \\
* * * \\
(0.0348)\end{array}$ & $\begin{array}{c}-0.0882 \\
* * \\
(0.0401)\end{array}$ & $\begin{array}{c}-0.0843 * \\
(0.0450)\end{array}$ & $\begin{array}{c}-0.0975 \\
* * \\
(0.0421)\end{array}$ & $\begin{array}{c}-0.0936 \text { * } \\
(0.0489)\end{array}$ \\
\hline lnto & & & & & $\begin{array}{c}0.457^{* * * *} \\
(0.0893)\end{array}$ & $\begin{array}{c}0.427^{* * * *} \\
(0.0993)\end{array}$ & $\begin{array}{l}0.494^{* * * *} \\
(0.0990)\end{array}$ & $\begin{array}{l}0.498 * * * \\
(0.0803)\end{array}$ \\
\hline lnfdipgdp & & & & & & $\begin{array}{c}-0.0225 \\
* * * \\
(0.00706)\end{array}$ & $\begin{array}{c}-0.0211 \\
* * * \\
(0.00698)\end{array}$ & $\begin{array}{c}-0.0237 \\
* * * \\
(0.00561)\end{array}$ \\
\hline lnggfcepgdp & & & & & & & $\begin{array}{c}0.281^{* * * *} \\
(0.0752)\end{array}$ & $\begin{array}{c}0.349 * * * \\
(0.115)\end{array}$ \\
\hline $\operatorname{lnfd}$ & & & & & & & & $\begin{array}{c}0.0256 \\
(0.0635)\end{array}$ \\
\hline Constant & $\begin{array}{c}7.510 * * * \\
(0.242)\end{array}$ & $\begin{array}{c}8.512 * * * \\
(0.257)\end{array}$ & $\begin{array}{c}8.484^{* * *} \\
(0.272)\end{array}$ & $\begin{array}{c}9.406^{* * *} \\
(0.222)\end{array}$ & $\begin{array}{c}7.169 * * * \\
(0.502)\end{array}$ & $\begin{array}{c}7.291 * * * \\
(0.517)\end{array}$ & $\begin{array}{c}6.114 * * * \\
(0.652)\end{array}$ & $\begin{array}{c}5.660^{* * *} \\
(0.568)\end{array}$ \\
\hline Observations & 476 & 476 & 432 & 432 & 432 & 398 & 398 & 345 \\
\hline Number of groups & 28 & 28 & 28 & 28 & 28 & 28 & 28 & 28 \\
\hline Unit effects Country & YES & YES & YES & YES & YES & YES & YES & YES \\
\hline Robust Kraay-Driscoll & YES & YES & YES & YES & YES & YES & YES & YES \\
\hline
\end{tabular}

Note: standard errors between parentheses; ${ }^{*}, * *$, and ${ }^{* * *}$ indicate significance at $10 \%, 5 \%$, and $1 \%$ levels, respectively. Source: own calculations. 
Table A6. The impact of using ICT infrastructure on economic growth (for all indicators used as proxies for ICT infrastructure).

\begin{tabular}{|c|c|c|c|c|}
\hline \multirow{3}{*}{ Variables } & \multicolumn{4}{|c|}{ Model: First Difference } \\
\hline & \multicolumn{4}{|c|}{ Dependent Variable: lngdp } \\
\hline & (1) & (2) & (3) & (4) \\
\hline $\operatorname{lnfbs} 100$ & $\begin{array}{c}0.0585^{* * *} \\
-0.0057\end{array}$ & & & \\
\hline $\operatorname{lnhbccp}$ & & $\begin{array}{c}0.1021 \text { *** } \\
-0.0175\end{array}$ & & \\
\hline lniuip & & & $\begin{array}{c}0.1914^{* * *} \\
-0.018\end{array}$ & \\
\hline $\operatorname{lnm} \operatorname{cs} 100$ & & & & $\begin{array}{c}0.2555^{* * *} \\
-0.0273\end{array}$ \\
\hline lngdfcfpgdp & $\begin{array}{c}-0.0828^{* *} \\
-0.0379\end{array}$ & $\begin{array}{l}-0.0377 \\
-0.0429\end{array}$ & $\begin{array}{l}-0.0295 \\
-0.0376\end{array}$ & $\begin{array}{l}-0.0608 \\
-0.0387\end{array}$ \\
\hline $\operatorname{lninf}$ & $\begin{array}{c}-0.0099 * * * \\
-0.0033\end{array}$ & $\begin{array}{c}-0.0109 * * * \\
-0.0037\end{array}$ & $\begin{array}{c}-0.0086^{* * *} \\
-0.0033\end{array}$ & $\begin{array}{c}-0.0109 * * * \\
-0.0033\end{array}$ \\
\hline lnunimpl & $\begin{array}{c}-0.1375^{* * *} \\
-0.0172\end{array}$ & $\begin{array}{c}-0.1351 \text { *** } \\
-0.0196\end{array}$ & $\begin{array}{c}-0.1343^{* * *} \\
-0.0171\end{array}$ & $\begin{array}{c}-0.1156^{* * *} \\
-0.0177\end{array}$ \\
\hline lnto & $\begin{array}{c}0.2734^{* * *} \\
-0.043\end{array}$ & $\begin{array}{c}0.2977^{* * *} \\
-0.0517\end{array}$ & $\begin{array}{c}0.2647^{* * *} \\
-0.0419\end{array}$ & $\begin{array}{c}0.2787^{* * *} \\
-0.043\end{array}$ \\
\hline lnfdipgdp & $\begin{array}{l}-0.0011 \\
-0.0027\end{array}$ & $\begin{array}{l}-0.0021 \\
-0.0032\end{array}$ & $\begin{array}{l}-0.0006 \\
-0.0027\end{array}$ & $\begin{array}{l}-0.0008 \\
-0.0028\end{array}$ \\
\hline lnggfcepgdp & $\begin{array}{c}-0.0945 \\
-0.068\end{array}$ & $\begin{array}{l}-0.0366 \\
-0.0851\end{array}$ & $\begin{array}{l}-0.0599 \\
-0.0666\end{array}$ & $\begin{array}{l}-0.0084 \\
-0.0682\end{array}$ \\
\hline $\operatorname{lnfd}$ & $\begin{array}{c}0.0473^{*} \\
-0.026\end{array}$ & $\begin{array}{c}0.0585^{* *} \\
-0.0293\end{array}$ & $\begin{array}{c}0.0743^{* * *} \\
-0.025\end{array}$ & $\begin{array}{c}0.0705^{* * *} \\
-0.0261\end{array}$ \\
\hline $\begin{array}{c}\text { Observations } \\
R^{2}\end{array}$ & 308 & 249 & 317 & 317 \\
\hline $\begin{array}{c}\mathrm{R}^{2} \\
\text { Adjusted } \mathrm{R}^{2}\end{array}$ & $\begin{array}{l}0.3289 \\
0.3132\end{array}$ & $\begin{array}{c}0.3256 \\
0.306\end{array}$ & $\begin{array}{l}0.2967 \\
0.2808\end{array}$ & $\begin{array}{l}0.2995 \\
0.2836\end{array}$ \\
\hline F Statistic & $1.7296(\mathrm{df}=7 ; 300)$ & $-0.7704(\mathrm{df}=7 ; 241)$ & $1.0136(\mathrm{df}=7 ; 309)$ & $-1.6779(\mathrm{df}=7 ; 309)$ \\
\hline
\end{tabular}

Note: standard errors between parentheses; ${ }^{*}, * *$, and ${ }^{* * *}$ indicate significance at $10 \%, 5 \%$, and $1 \%$ levels, respectively. Source: own calculations.

\section{References}

1. World Economic Forum. The Global Information Technology Report 2013, Digitization for Economic Growth and Job Creation. 2013. Available online: http:/ / www3.weforum.org/docs/WEF_GITR_Report_2013.pdf (accessed on 10 July 2018).

2. OECD. ICTs for Development: Improving Policy Coherence; OECD: Paris, France, 2010.

3. World Bank. Information and Communication Technologies: A World Bank Group Strategy; World Bank: Washington, DC, USA, 2002.

4. Pradhan, R.P.; Mallik, G.; Bagchi, T.P. Information communication technology (ICT) infrastructure and economic growth: A causality evinced by cross-country panel data. IIMB Manag. Rev. 2018, 30, 91-103. [CrossRef]

5. Sepehrdoust, H. Impact of information and communication technology and financial development on economic growth of OPEC developing economies. Kasetsart J. Soc. Sci. 2018. [CrossRef]

6. Meijers, H. Does the Internet generate economic growth, international trade, or both? Int. Econ. Econ. Policy 2014, 11, 137-163. [CrossRef]

7. Chen, Y.; Gong, X.; Chu, C.C.; Cao, Y. Access to the Internet and Access to Finance: Theory and Evidence. Sustainability 2018, 10, 2534. [CrossRef]

8. Roller, L.H.; Waverman, L. Telecommunications infrastructure and economic development: A simultaneous approach. Am. Econ. Rev. 2001, 91, 909-923. [CrossRef]

9. OECD. The Economic Impact of ICT: Measurement, Evidence and Implications; OECD: Paris, France, 2004. 
10. Piatkowski, M. The impact of ICT on Growth in transition economies. TIGER Work. Pap. Ser. 2004, 59. Available online: http:/ / www.tiger.edu.pl/publikacje/TWPNo59.pdf (accessed on 15 June 2018).

11. Piatkowski, M. Can information and communication technologies make a difference in the development of transition economies? Inf. Technol. Int. Dev. 2006, 3, 39-53. [CrossRef]

12. Qiang, C.Z.W.; Pitt, A. Contribution of information and Communication Technologies to Growth. In World Bank Working Paper; World Bank: Washington, DC, USA, 2004.

13. Jalava, J.; Pohjola, M. ICT as a source of output and productivity growth in Finland. Telecommun. Policy 2007, 31, 463-472. [CrossRef]

14. Vu, K.M. ICT as a source of economic growth in the information age: Empirical evidence from the 1996-2005 period. Telecommun. Policy 2011, 35, 357-372. [CrossRef]

15. Ahmed, E.M.; Ridzuan, R. The impact of ICT on East Asian economic growth: Panel estimation approach. J. Knowl. Econ. 2013, 4, 540-555. [CrossRef]

16. Lin, H.J.; Lin, W.T. International E-banking: ICT Investments and the Basel Accord. J. Comp. Int. Manag. 2007, 10, 23-39.

17. Stoica, O.; Mehdian, S.; Sargu, A. The impact of Internet banking on the performance of Romanian banks: DEA and PCA approach. Procedia Econ. Financ. 2015, 20, 610-622. [CrossRef]

18. Ghita-Mitrescu, S.; Duhnea, C. Internet Banking in Romania at a Glance. Ovidius Univ. Ann. Econ. Sci. Ser. 2016, 16, 508-514.

19. Madden, G.; Savage, S.J. CEE telecommunications investment and economic growth. Inf. Econ. Policy 1998, 10, 173-195. [CrossRef]

20. Datta, A.; Agarwal, S. Telecommunications and economic growth: A panel data approach. Appl. Econ. 2004, 36, 1649-1654. [CrossRef]

21. Shiu, A.; Lam, P.L. Causal Relationship between Telecommunications and Economic Growth: A Study of 105 Countries. In Proceedings of the 17th Biennial Conference of the International Telecommunications Society (ITS), Montreal, QC, Canada, 24-27 June 2008; Available online: http:/ /www.imaginar.org/taller/its2008 / 192.pdf (accessed on 10 June 2018).

22. Cieślik, A.; Kaniewska, M. Telecommunications infrastructure and regional economic development: The case of Poland. Reg. Stud. 2004, 38, 713-725. [CrossRef]

23. Czernich, N.; Falck, O.; Kretschmer, T.; Woessmann, L. Broadband Infrastructure and Economic Growth. In CESifo Working Paper Series; 2009; Volume 2861, Available online: https:/ / papers.ssrn.com/sol3/papers. cfm?abstract_id=1516232 (accessed on 20 June 2018).

24. Choi, C.; Yi, M.H. The effect of the Internet on economic growth: Evidence from cross-country. Econ. Lett. 2009, 105, 39-41. [CrossRef]

25. Salahuddin, M.; Gow, J. The effects of Internet usage, financial development and trade openness on economic growth in South Africa: A time series analysis. Telemat. Inform. 2016, 33, 1141-1154. [CrossRef]

26. Najarzadeh, R.; Rahimzadeh, F.; Reed, M. Does the Internet increase labor productivity? Evidence from a cross-country dynamic panel. J. Policy Model. 2014, 36, 986-993. [CrossRef]

27. Nasab, E.H.; Aghaei, M. The effect of ICT on economic growth: Further evidence. Int. Bull. Bus. Adm. 2009, $5,46-56$.

28. Qiang, C.Z.W.; Rossotto, C.M.; Kimura, K. Economic impacts of broadband. In Information and Communications for Development 2009: Extending Reach and Increasing Impact; World Bank: Washington, DC, USA, 2009; Chapter 3; pp. 35-50. Available online: http:/ / siteresources.worldbank.org/EXTIC4D/ Resources/IC4D_Broadband_35_50.pdf (accessed on 20 June 2018).

29. Crandall, R.W.; Singer, H.J. The Economic Impact of Broadband Investment; Broadband for America: Washington, DC, USA, 2010; Available online: http:/ / Internetinnovation.org/files/special-reports/Economic_Impact_ of_Broadband_Investment_Broadband_for_America_.pdf (accessed on 25 June 2018).

30. Dimelis, S.P.; Papaioannou, S.K. FDI and ICT effects on productivity growth: A comparative analysis of developing and developed countries. Eur. J. Dev. Res. 2010, 22, 79-96. [CrossRef]

31. Thompson, H.G., Jr.; Garbacz, C. Economic impacts of mobile versus fixed broadband. Telecommun. Policy 2011, 35, 999-1009. [CrossRef]

32. Zagorchev, A.; Vasconcellos, G.; Bae, Y. Financial development, technology, growth and performance: Evidence from the accession to the EU. J. Int. Financ. Mark. Inst. Money 2011, 21, 743-759. [CrossRef] 
33. Yousefi, A. The Impact of Information and Communication Technology on Economic Growth: Evidence from Developed and Developing Countries. Econ. Innov. New Technol. 2011, 20, 581-596. [CrossRef]

34. Veeramacheneni, B.; Ekanayake, E.M.; Vogel, R. Information technology and economic growth: A causal analysis. Southwest. Econ. Rev. 2011, 34, 75-88.

35. Farhadi, M.; Ismail, R.; Fooladi, M. Information and communication technology use and economic growth. PLOS ONE 2012, 7, e48903. [CrossRef] [PubMed]

36. Ng, T.H.; Lye, C.T.; Lim, Y.S. Broadband penetration and economic growth in ASEAN countries: A generalized method of moments approach. Appl. Econ. Lett. 2013, 9, 857-862. [CrossRef]

37. Lovrić, L. Information-Communication Technology Impact on Labor Productivity Growth of EU Developing Countries. J. Econ. Bus. 2012, 30, 223-245.

38. Sassi, S.; Goaied, M. Financial development, ICT diffusion and economic growth: Lessons from MENA region. Telecommun. Policy 2013, 37, 252-261. [CrossRef]

39. Gruber, H.; Hatonen, J.; Koutroumpis, P. Broadband access in the EU: An assessment of future economic benefits. Telecommun. Policy 2014, 18, 1046-1058. [CrossRef]

40. Pradhan, R.P.; Arvin, M.B.; Norman, N.R.; Bele, S.K. Economic growth and the development of telecommunications infrastructure in the G-20 countries: A panel-VAR approach. Telecommun. Policy 2014, 38, 634-649. [CrossRef]

41. Pradhan, R.P.; Arvin, M.B.; Hall, J.H. Economic growth, development of telecommunications infrastructure, and financial development in Asia, 1991-2012. Q. Rev. Econ. Financ. 2016, 59, 25-38. [CrossRef]

42. Niebel, T. ICT and economic growth-Comparing developing, emerging and developed countries. World Dev. 2018, 104, 197-211. [CrossRef]

43. Majeed, M.T.; Ayub, T. Information and Communication Technology (ICT) and Economic Growth Nexus: A Comparative Global Analysis. Pak. J. Commer. Soc. Sci. 2018, 12, 443-476.

44. Haftu, G.G. Information communications technology and economic growth in Sub-Saharan Africa: A panel data approach. Telecommun. Policy 2018. [CrossRef]

45. Latif, Z.; Latif, S.; Ximei, L.; Pathan, Z.H.; Salam, S.; Jianqiu, Z. The dynamics of ICT, foreign direct investment, globalization and economic growth: Panel estimation robust to heterogeneity and cross-sectional dependence. Telemat. Inform. 2018, 35, 318-328. [CrossRef]

46. Etro, F. The economic impact of cloud computing on business creation, employment and output in Europe. Rev. Bus. Econ. 2009, 54, 179-208.

47. European Commission. Unleashing the Potential of Cloud Computing in Europe. 2012. Available online: https:/ / eur-lex.europa.eu/LexUriServ/LexUriServ.do?uri=COM:2012:0529:FIN:EN:PDF (accessed on 10 September 2018).

48. European Commission. A Digital Single Market Strategy for Europe. 2015. Available online: https: / / eur-lex.europa.eu/legal-content/EN/TXT/PDF/?uri=CELEX:52015DC0192\&from=EN (accessed on 10 September 2018).

49. Palos-Sanchez, P.R. Drivers and Barriers of the Cloud Computing in SMEs: The Position of the European Union. Harv. Deusto Bus. Res. 2017, 6, 116-132. [CrossRef]

50. Giannakouris, K.; Smihily, M. Cloud Computing-Statistics on the Use by Enterprises. 2016. Available online: https://ec.europa.eu/eurostat/statistics-explained/index.php/Cloud_computing_-_ statistics_on_the_use_by_enterprises (accessed on 10 September 2018).

51. International Telecommunications Union (ITU). Country ICT Data. 2018. Available online: https://www.itu. int/en/ITU-D/Statistics/Pages/stat/default.aspx (accessed on 10 June 2018).

52. OECD. Gross Domestic Product (GDP) (Indicator). 2018. Available online: https://data.oecd.org/gdp/ gross-domestic-product-gdp.htm (accessed on 10 June 2018).

53. World Bank. World Development Indicators. 2018. Available online: http://data.worldbank.org/datacatalog/worlddevelopment-indicators (accessed on 10 June 2018).

54. European Commission. Eurostat. 2018. Available online: http://ec.europa.eu/eurostat (accessed on 10 June 2018).

55. Pohjola, M. New economy in growth and development. Oxf. Rev. Econ. Pol. 2002, 18, 380-396. [CrossRef]

56. Croissant, Y.; Millo, G. Panel Data Econometrics in R: The plm Package. J. Stat. Softw. 2008, $27,1-43$. [CrossRef]

57. Mundlak, Y. On the Pooling of Time Series and Cross Section Data. Econometrica 1978, 46, 69-85. [CrossRef] 
58. Hausman, J.A. Specification Tests in Econometrics. Econometrica 1978, 46, 1251-1271. [CrossRef]

59. Roodman, D. How to Do xtabond2: An Introduction to "Difference" and "System" GMM in Stat. In Working Paper; Center for Global Development: Washington, DC, USA, 2006; Volume 103.

60. Roodman, D. A note on the theme of too many instruments. Oxf. B Econ. Stat. 2009, 71, 135-158. [CrossRef]

61. Gujarati, D.N.; Porter, D.C.; Gunasekar, S. Basic Econometrics, 5th ed.; Tata McGraw-Hill Education Pvt. Ltd.: New York, NY, USA, 2013.

62. Baltagi, B.H.; Li, Q. A Lagrange multiplier test for the error components model with incomplete panels. Econ. Rev. 1990, 9, 103-107. [CrossRef]

63. Driscoll, J.C.; Kraay, A.C. Consistent covariance matrix estimation with spatially dependent panel data. Rev. Econ. Stat. 1998, 80, 549-560. [CrossRef]

64. Hodrab, R.; Maitah, M.; Smutka, L. The effect of information and communication technology on economic growth: Arab world case. IJEFI 2016, 6, 765-775.

65. Bojnec, Š.; Fertő, I. Broadband availability and economic growth. Ind. Manag. Data Syst. 2012, 112, 1292-1306. [CrossRef]

66. Melnyk, L.; Kubatko, O.; Pysarenko, S. The impact of foreign direct investment on economic growth: Case of post communism transition economies. Probl. Perspect. Manag. 2014, 12, 17-24.

67. Rusu, V.D.; Toderascu, C. Improving the Competitiveness in CEE Countries by Sustaining the Development of Financial Market. J. Account. Manag. 2016, 6, 5-14.

(C) 2018 by the authors. Licensee MDPI, Basel, Switzerland. This article is an open access article distributed under the terms and conditions of the Creative Commons Attribution (CC BY) license (http://creativecommons.org/licenses/by/4.0/). 